\title{
Targeting Apoptotic Activity Against Prostate Cancer Stem Cells
}

\author{
Dagmara Jaworska * and Ewelina Szliszka \\ Department of Microbiology and Immunology, School of Medicine with the Division of Dentistry in Zabrze, \\ Medical University of Silesia in Katowice, Jordana 19, 41-808 Zabrze, Poland; eszliszka@sum.edu.pl \\ * Correspondence: djaworska@sum.edu.pl; Tel./Fax: +48-322-722-554
}

Received: 28 June 2017; Accepted: 26 July 2017; Published: 29 July 2017

\begin{abstract}
Numerous data suggest that an increase of cancer stem cells (CSCs) in tumor mass can be the reason for failure of conventional therapies because of their resistance. CD44+/CD24- cells are a putative cancer stem cells subpopulation in prostate cancer. TRAIL (tumor necrosis factor-related apoptosis-inducing ligand) is an activator of apoptosis in tumor cells. However, some tumors are TRAIL-resistant. Cancer cells can be re-sensitized to TRAIL induced apoptosis by a combination of TRAIL and taxanes. The aim of this work was to analyze the enhancement of the anticancer effect of TRAIL by paclitaxel, cabazitaxel and docetaxel in the whole population of PC3 and DU145 prostate cancer cells, but also in CD44+/CD24- prostate cancer stem cells. We examined the apoptotic effect of TRAIL and taxanes using flow cytometry and Annexin-V-PE staining. The co-treatment with taxanes and TRAIL enhanced significantly the apoptosis in CD44+/CD24- cells only in PC3 cell line but not in DU145 cells. We discovered also that taxanes can increase the expression of death receptor TRAIL-R2 in PC3 prostate cancer cells. The results of our study show that treatment with paclitaxel, cabazitaxel and docetaxel is able to enhance the apoptosis induced by TRAIL even in prostate cancer stem cells.
\end{abstract}

Keywords: prostate cancer stem cells; TRAIL; apoptosis; paclitaxel; cabazitaxel; docetaxel

\section{Introduction}

Prostate cancer represents one of the most prevalent cancers diagnosed in men and remains the second leading cause of cancer related deaths in Europe and the United States [1-3].

In the last decades, prostate cancer research focused on the hypothesis concerning cancer stem cells (CSCs) and their role in the development of prostate cancer. CSCs were described as a small population of cells that are clonogenic and "possess the capacity to self-renew and to cause the heterogeneous lineages of cancer cells that comprise the tumor" [4-8].

Prostate cancer stem cells were characterized by the expression of several markers such as CD24, CD44, CD49f, CD133, CD166, and $\alpha 2 \beta 1$ integrins [6,9-13]. However, the ideal combination which could result in distinction of cancer stem cells have not been found yet, because of prostate cancer genetic heterogeneity.

In 2006, Patrawala et al. [14] demonstrated that CD44+ prostate cancer cells have increased metastatic potential, form colonies in soft agar and tumors in NOD/SCID mice. Afterwards, Hurt et al. [9] discovered that CD44+/CD24- prostate cancer cells have the unique ability to grow as nonadherent spheres in serum replacement medium and have the potential to form tumors in NOD/SCID mice. This marker combination let them identify putative prostate cancer stem cells. Next, studies also identified CD44+/CD24- prostate cancer cells in established prostate cancer cell lines and showed that these subpopulations were more invasive, tumorigenic and were able to differentiate into mature tumor cells expressing highly aggressive phenotype [8,15-17]. 
Those stem-like cells appear to be tumor initiators and possess increased resistance to conventional anti-cancer treatment because of their quiescence $[7,18]$.

Cancer stem cells with their increased resistance to antitumor agents can also be unaffected by the immune system mechanisms such as the activation of apoptosis by TRAIL (tumor necrosis factor-related apoptosis-inducing ligand). Cells that exhibit this level of resistance could have been able to escape immune surveillance and become the origin of the neoplastic process.

TRAIL is a type II membrane protein and it is a member of the tumor necrosis factor (TNF) cytokines superfamily. This molecule induces apoptosis upon binding to its death domain-containing transmembrane receptors: TRAIL-R1 (DR4) and TRAIL-R2 (DR5) [19-21]. Other TRAIL receptors exist, which are unable to induce apoptosis. TRAIL-R3 and TRAIL-R4 are known as decoy receptor-1 and -2, because they can inhibit TRAIL-induced apoptosis. Presumably, these receptors protect normal cell from apoptosis induced by ligand TRAIL [19,22]. Ligand induces selectively cell death only in cancer cells, showing little or no toxicity against normal cells. Although TRAIL specifically induces cell death in cancer cells, they can still have resistance to TRAIL-mediated cytotoxicity. In this mechanism of insubordination, an increased expression of anti-apoptotic protein or decreased expression of death receptors (DR4 and DR5) is involved [20,23,24].

Many patients with prostate cancer treated with radical prostatectomy or radiotherapy develop advanced disease and will suffer castration-resistant prostate cancer (CRPC) [25]. Presently, therapies for CRPC include systemic drugs and agents targeted at androgen signaling (novel hormonal agents such as abiraterone and enzalutamide). Food and Drug Administration (FDA)-approved chemotherapy available for patients with prostate cancer includes taxanes, a microtubule-stabilizing drugs, especially docetaxel and cabazitaxel. These drugs bring clinical and survival benefits for many patients, however, due to primary or acquired resistance, their disease will eventually continue to progress [26-29].

Much clinical evidence suggests that cancer stem cells existing in the tumor mass may contribute to treatment failure because of increased chemoresistance to conventional anticancer agents [9,30-34].

Cancer stem cells are likely to be more resistant to anti-cancer immune surveillance, such as the process of apoptosis induced by TRAIL ligand. The aim of this study was to prove the hypothesis that cancer stem cells (CSCs) present in the population of prostate cancer cells can be responsible for the increased resistance of the tumor for the natural immune system anticancer agents such as ligand TRAIL. The apoptotic effect of TRAIL in combination with taxanes have been tested in the whole population of PC3 and DU145 prostate cancer cells, but also in CD44+/CD24- prostate cancer stem cells subpopulation within both cell lines to examine if this compounds can augment the anti-cancer effect of TRAIL.

\section{Results}

2.1. Apoptotic Activity of TRAIL (Tumor Necrosis Factor-Related Apoptosis-Inducing Ligand) in DU145 and PC3 Prostate Cancer Cell Lines

The apoptotic effect of TRAIL at the concentration of $100 \mathrm{ng} / \mathrm{mL}$ following a $48 \mathrm{~h}$ incubation was $12.3 \% \pm 2.3 \%$ of apoptotic cells in PC 3 cell line and $13.3 \% \pm 0.9 \%$ of apoptotic cells in DU145 cell line. Apoptotic effect analyzed by flow cytometry is presented in Figure 1. Our data confirm that both analyzed cell lines are TRAIL-resistant. 


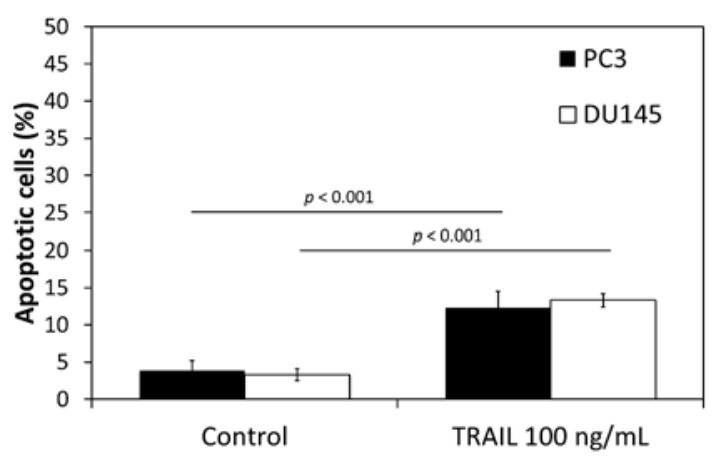

Figure 1. Apoptotic effect of TRAIL (Tumor necrosis factor-related apoptosis-inducing ligand) $(100 \mathrm{ng} / \mathrm{mL})$ in DU145 and PC3 prostate cancer cells. The values represent mean $\pm \mathrm{SD}(n=6)$.

\subsection{Apoptotic Activity of Paclitaxel, Cabazitaxel or Docetaxel in DU145 and PC3 Prostate Cancer Cell Lines}

The apoptotic effect of paclitaxel, cabazitaxel and docetaxel against PC3 and DU145 cells depends on a concentration of the tested compound. In our study, we used tested compounds in the concentrations from $0.1 \mu \mathrm{M}$ to $1 \mu \mathrm{M}$. The most effective concentrations were $0.25 \mu \mathrm{M}$ and $0.5 \mu \mathrm{M}$. Further increasing the concentration of tested compounds does not have a significant effect on apoptosis level.

Paclitaxel induced apoptosis in $33.4 \% \pm 5.8 \%$ of cancer cells in a concentration of $0.25 \mu \mathrm{M}$ and $33.9 \% \pm 5.1 \%$ in a concentration of $0.5 \mu \mathrm{M}$ in PC3 cells after a $48 \mathrm{~h}$ incubation. Cabazitaxel induced apoptosis in $31.6 \% \pm 5.9 \%$ of cancer cells in a concentration of $0.25 \mu \mathrm{M}$ and $33.9 \% \pm 5.1 \%$ in a concentration of $0.5 \mu \mathrm{M}$ in PC 3 cells. In the same cell line docetaxel induced apoptosis in $37.3 \% \pm 3.4 \%$ cells in a concentration of $0.25 \mu \mathrm{M}$ and $40.3 \% \pm 6.4 \%$ in a concentration of $0.5 \mu \mathrm{M}$. Apoptotic effects of paclitaxel, cabazitaxel and docetaxel determined by flow cytometry in PC3 cell line are presented in Figure 2a.

In the other tested prostate cancer cell line DU145, paclitaxel induced apoptosis in $14.1 \% \pm 1.2 \%$ cells in a concentration of $0.25 \mu \mathrm{M}$ and $14.4 \% \pm 1.8 \%$ in a concentration of $0.5 \mu \mathrm{M}$ after a $48 \mathrm{~h}$ incubation, whereas cabazitaxel induced apoptosis in $13.7 \pm 2.3 \%$ cells in a concentration of $0.25 \mu \mathrm{M}$ and $15.3 \% \pm 2.2 \%$ in a concentration of $0.5 \mu \mathrm{M}$ in DU145 cells. Docetaxel induced apoptosis in $15.3 \% \pm 1.90 \%$ cells in a concentration of $0.25 \mu \mathrm{M}$ and $15.6 \% \pm 0.9 \%$ in a concentration of $0.5 \mu \mathrm{M}$ in DU45 prostate cancer cell line. Therefore, DU145 prostate cancer cells were more resistant to apoptotic activity of used taxanes. Apoptotic effects of paclitaxel, cabazitaxel and docetaxel determined by flow cytometry in DU145 cell line are presented in Figure 2b.

\subsection{Apoptotic Activity of TRAIL in Combination with Paclitaxel, Cabazitaxel or Docetaxel in DU145 and PC3 Prostate Cancer Cell Lines}

The combined treatment of TRAIL and paclitaxel, cabazitaxel or docetaxel significantly increased the apoptotic effect on PC3 and DU145 prostate cancer cells compared to TRAIL or taxane used alone. We examined the apoptotic effect of $100 \mathrm{ng} / \mathrm{mL}$ TRAIL in combination with $0.25 \mu \mathrm{M}$ and $0.5 \mu \mathrm{M}$ paclitaxel, cabazitaxel or docetaxel against PC 3 and DU145 prostate cancer cells. Figure 2 demonstrates the percentage of apoptotic cells stained with Annexin V-PE and analyzed by flow cytometry in PC3 (Figure 2a) and DU145 (Figure 2b).

Combined treatment with TRAIL and paclitaxel induced apoptosis in $63.4 \% \pm 8.1 \%$ of cancer cells in a concentration of $0.25 \mu \mathrm{M}$ and $65.3 \% \pm 8.7 \%$ in a concentration of $0.5 \mu \mathrm{M}$ in PC 3 cells after a $48 \mathrm{~h}$ incubation. Cabazitaxel and TRAIL induced apoptosis in $62.3 \% \pm 9.3 \%$ of cancer cells in a concentration of $0.25 \mu \mathrm{M}$ and $66.1 \% \pm 8.8 \%$ in a concentration of $0.5 \mu \mathrm{M}$ in PC 3 cells. In the same cell line combination of TRAIL and docetaxel induced apoptosis in $69.0 \% \pm 2.8 \%$ cells in a concentration of $0.25 \mu \mathrm{M}$ and $72.6 \% \pm 5.8 \%$ in a concentration of $0.5 \mu \mathrm{M}$. 
In the DU145 prostate cancer cell line, co-treatment with paclitaxel and TRAIL induced apoptosis in $27.5 \% \pm 3.8 \%$ cells in a concentration of $0.25 \mu \mathrm{M}$ and $28.0 \% \pm 3.4 \%$ in a concentration of $0.5 \mu \mathrm{M}$ after a $48 \mathrm{~h}$ incubation, whereas cabazitaxel and TRAIL induced apoptosis in $24.5 \% \pm 3.75 \%$ cells in a concentration of $0.25 \mu \mathrm{M}$ and $24.9 \% \pm 3.9 \%$ in a concentration of $0.5 \mu \mathrm{M}$ in DU145 cells. Docetaxel and TRAIL co-treatment induced apoptosis in $28.6 \% \pm 7.35 \%$ cells in a concentration of $0.25 \mu \mathrm{M}$ and $28.6 \% \pm 3.5 \%$ in a concentration of $0.5 \mu \mathrm{M}$ in DU45 prostate cancer cell line. DU145 prostate cancer cells were more resistant to TRAIL and taxanes activity compared to PC 3 cells.

The data indicate that paclitaxel, cabazitaxel and docetaxel augment the apoptotic activity of TRAIL against both prostate cancer cell lines and sensitize these TRAIL-resistant cells to apoptotic activity of TRAIL.

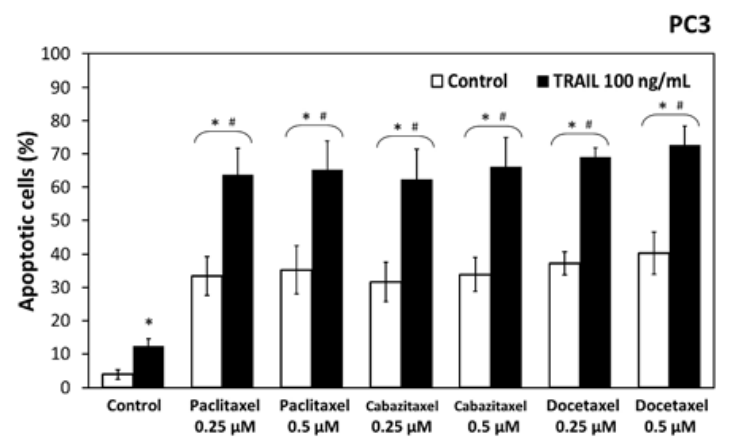

(a)

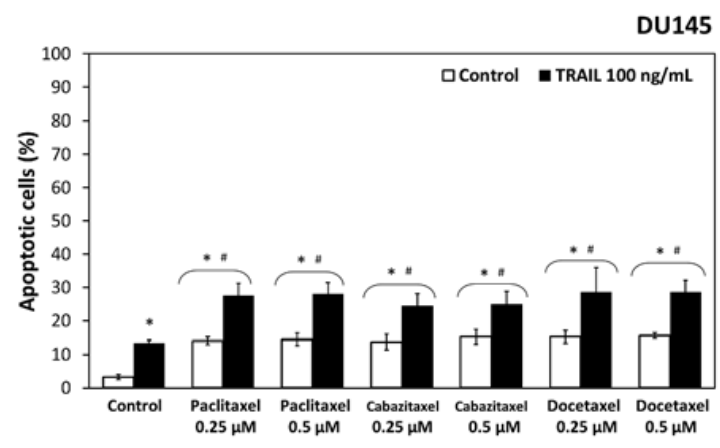

(b)

Figure 2. Apoptotic effect of TRAIL (100 ng/mL) in combination with paclitaxel, cabazitaxel and docetaxel in DU145 and PC3 prostate cancer cells: (a) apoptotic effect in PC3 cells; and (b) apoptotic effect in DU145 cells. ${ }^{*} p<0.001$, significantly different from the respective control; $\# p<0.001$, significantly different from TRAIL alone. The values represent mean $\pm \operatorname{SD}(n=6)$.

\subsection{Necrotic Effect of TRAIL and/or Paclitaxel, Cabazitaxel, Docetaxel in DU145 and PC3 Prostate Cancer Cell Lines}

The necrotic cell death percentage in PC3 and DU145 cells treated with paclitaxel, cabazitaxel and docetaxel examined by LDH assay was almost in all cases not significant compared to the control. In the flow cytometry test with 7-AAD, necrotic effect of TRAIL and/or paclitaxel, cabazitaxel and docetaxel in PC3 and DU145 cells was not significant compared to control. Therefore, in this test, no significant necrotic effect was shown in PC3 and DU145 prostate cancer cell lines.

\subsection{Cancer Stem Cells in DU145 and PC3 Prostate Cancer Cell Lines}

Using flow cytometry we identified CD44+/CD24- subpopulation in PC3 and DU145 human prostate cancer cell lines. As Hurt et al. reported, it is a small subpopulation in prostate cancer cell lines with increased clonogenic properties, tumorigenic capacity and stem-like characteristics [9]. Therefore in this paper, we used abbreviation CSCs for the CD44+/CD24- subpopulation and non-CSCs for the CD44+/CD24- depleted subpopulation.

In the PC3 cell line, the CSCs subpopulation was $11.4 \% \pm 1.9 \%$, whereas, in the DU145 cell line, $12.6 \% \pm 0.9 \%$. Figure 3 presents subpopulations gated in the PC3 (Figure 3a) and DU145 (Figure $3 b$ ) prostate cancer cells. CSCs subpopulation was marked blue, non-CSCs subpopulation was marked green. 


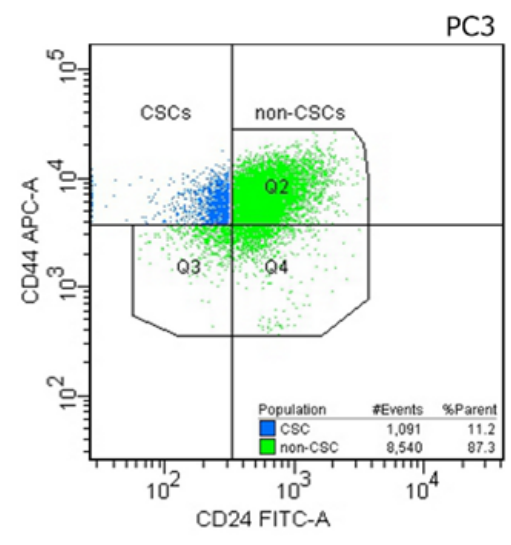

(a)

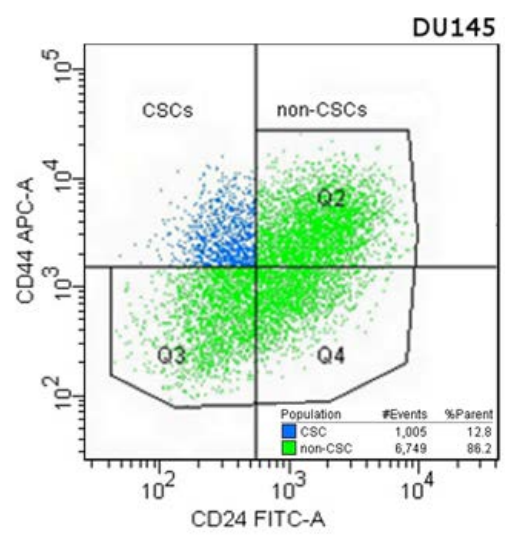

(b)

Figure 3. Cytometric analysis of Cancer Stem Cells in: PC3 (a) and DU145 (b) prostate cancer cell lines. Cells were incubated with anti-CD24 FITC-labeled and anti-CD44 APC-labeled antibodies. CD44+/CD24- population marked as blue (CSCs), the CD44+/CD24- depleted population marked as green (non-CSCs). Gates were established based on the appropriate isotype controls.

\subsection{Apoptotic Activities of TRAIL within the Subpopulations in DU145 and PC3 Prostate Cancer Cell Lines}

Apoptosis was measured by flow cytometry using the Apoptosis-PE Kit with Annexin V, anti-CD24-FITC and anti-CD44-APC monoclonal antibodies were used simultaneously to distinguish CSCs and non-CSCs subpopulation. The CSCs and non-CSCs subpopulation were gated in the FACS DIVA software (Figure 3), and for each population the apoptotic cells number was measured according to Annexin V-PE expression.

Our results showed that CSCs in the PC3 and DU145 prostate cancer cells were significantly more resistant to apoptosis mediated by TRAIL compared to non-CSCs. Within PC3 cells the apoptotic effect of TRAIL at the concentration of $100 \mathrm{ng} / \mathrm{mL}$ following a $48 \mathrm{~h}$ incubation was $4.3 \% \pm 0.9 \%$ of killed CSCs and $16.0 \% \pm 2.7 \%$ of killed non-CSCs. In DU145 cells, apoptotic effect of $100 \mathrm{ng} / \mathrm{mL}$ TRAIL was $4.0 \% \pm 1.7 \%$ of killed CSCs and $15.9 \% \pm 1.7 \%$ of killed non-CSCs. Apoptotic effects analyzed by flow cytometry are presented in Figures 4 and 5.

\subsection{Apoptotic Activities of Paclitaxel, Cabazitaxel or Docetaxel within the Subpopulations in DU145 and PC3} Prostate Cancer Cell Lines

We have discovered that CSCs in the PC 3 and DU145 prostate cancer cells were also more resistant to apoptosis mediated by taxanes compared to non-CSCs. Within PC3 cells the apoptotic effect of paclitaxel at the concentrations of $0.25 \mu \mathrm{M}$ and $0.5 \mu \mathrm{M}$ following a $48 \mathrm{~h}$ incubation was respectively $13.2 \% \pm 1.3 \%$ and $13.2 \% \pm 1.6 \%$ of killed CSCs whereas as much as $50.4 \% \pm 8.2 \%$ and $54.8 \% \pm 4.7 \%$ non-CSCs went apoptosis. Cabazitaxel at the concentrations of $0.25 \mu \mathrm{M}$ and $0.5 \mu \mathrm{M}$ killed respectively $10.7 \% \pm 2.7 \%$ and $13.3 \% \pm 3.3 \%$ CSCs while $41.6 \% \pm 8.5 \%$ and $45.6 \% \pm 9.0 \%$ non-CSCs went apoptosis. Eventually docetaxel at the concentrations of $0.25 \mu \mathrm{M}$ and $0.5 \mu \mathrm{M}$ killed respectively $13.35 \% \pm 3.5 \%$ and $15.1 \% \pm 1.6 \%$ CSCs whereas $52.6 \% \pm 5.2 \%$ and $54.4 \% \pm 5.4 \%$ non-CSCs went apoptosis.

Subsequently, DU145 cells appear to be more resistant then PC3 cells, however the most resistant were again CSCs. The apoptotic effect of paclitaxel on DU145 cells at the concentrations of $0.25 \mu \mathrm{M}$ and $0.5 \mu \mathrm{M}$ following a $48 \mathrm{~h}$ incubation was respectively $4.5 \% \pm 0.7 \%$ and $4.6 \% \pm 2.0 \%$ of killed CSCs whereas $16.1 \% \pm 1.1 \%$ and $16.3 \% \pm 2.8 \%$ non-CSCs went apoptosis. Cabazitaxel at the concentrations of $0.25 \mu \mathrm{M}$ and $0.5 \mu \mathrm{M}$ killed respectively $3.6 \% \pm 1.1 \%$ and $4.8 \% \pm 3.3 \%$ CSCs, while $15.7 \% \pm 2.5 \%$ and $17.5 \% \pm 2.3 \%$ non-CSCs went apoptosis. Ultimately, docetaxel at the concentrations of $0.25 \mu \mathrm{M}$ and $0.5 \mu \mathrm{M}$ killed, respectively, $4.3 \% \pm 1.9 \%$ and $4.4 \% \pm 1.1 \%$ CSCs, whereas $17.2 \% \pm 2.1 \%$ and $16.8 \% \pm 1.0 \%$ non-CSCs went apoptosis. The results of flow cytometric analysis are presented in Figures 4 and 5 . 
2.8. Apoptotic Activities of TRAIL in combination with Paclitaxel, Cabazitaxel or Docetaxel within the Subpopulations in DU145 and PC3 Prostate Cancer Cell Lines

Our results showed that combined treatment of TRAIL and taxanes significantly enhanced the apoptotic effect on both subpopulations in PC3 prostate cancer cells compared to TRAIL or taxanes alone, whilst, in DU145 cells, the CSCs were resistant to apoptosis mediated by combination of taxanes and TRAIL. The co-treatment of TRAIL and taxanes augmented apoptosis effect only in non-CSCs subpopulation within DU145 cells.

Within PC3 cells the co-treatment of cancer cells with TRAIL at the concentration of $100 \mathrm{ng} / \mathrm{mL}$ and paclitaxel at the concentrations of $0.25 \mu \mathrm{M}$ and $0.5 \mu \mathrm{M}$ increased the percentage of apoptotic cells, respectively, to $30.2 \% \pm 5.7 \%$ and $34.2 \% \pm 4.1 \%$ in CSCs subpopulation, and to $72.6 \% \pm 7.1 \%$ and $75.9 \% \pm 7.3 \%$ in non-CSCs subpopulation. After exposure to $100 \mathrm{ng} / \mathrm{mL}$ TRAIL and cabazitaxel at the concentrations of $0.25 \mu \mathrm{M}$ and $0.5 \mu \mathrm{M}$, the apoptotic cells percentage was elevated to $29.6 \% \pm 3.5 \%$ and $29.6 \% \pm 6.1 \%$ within CSCs and to $71.6 \% \pm 8.3 \%$ and $74.8 \% \pm 9.2 \%$ in non-CSCs. Eventually, the co-treatment of $100 \mathrm{ng} / \mathrm{mL}$ TRAIL and docetaxel at the concentrations of $0.25 \mu \mathrm{M}$ and $0.5 \mu \mathrm{M}$ killed respectively $36.7 \% \pm 4.2 \%$ and $35.8 \% \pm 4.2 \%$ CSCs whereas $73.7 \% \pm 4.8 \%$ and $81.3 \% \pm 6.4 \%$ non-CSCs went apoptosis.

DU145 cells occur to be more resistant then PC3 cells, co-treatment with taxane and TRAIL has no significant impact on CSCs. Only non-CSCs appear to be more susceptible for simultaneous treatment with TRAIL and taxane. The apoptotic effect of $100 \mathrm{ng} / \mathrm{mL}$ TRAIL and paclitaxel at the concentrations of $0.25 \mu \mathrm{M}$ and $0.5 \mu \mathrm{M}$ following a $48 \mathrm{~h}$ incubation was respectively $6.3 \% \pm 1.1 \%$ and $6.4 \% \pm 1.7 \%$ of killed CSCs, whereas $28.3 \% \pm 3.5 \%$ and $29.5 \% \pm 3.3 \%$ non-CSCs went apoptosis. TRAIL and cabazitaxel at the concentrations of $0.25 \mu \mathrm{M}$ and $0.5 \mu \mathrm{M}$ killed, respectively, $3.9 \% \pm 1.7 \%$ and $5.5 \% \pm 0.9 \%$ CSCs, while $25.5 \% \pm 4.2 \%$ and $26.0 \% \pm 4.7 \%$ non-CSCs went apoptosis. Ultimately, co-treatment with TRAIL and docetaxel at the concentrations of $0.25 \mu \mathrm{M}$ and $0.5 \mu \mathrm{M}$ killed, respectively, $5.9 \% \pm 1.5 \%$ and $4.8 \% \pm 0.9 \%$ CSCs, whereas $30.7 \% \pm 8.5 \%$ and $30.8 \% \pm 3.6 \%$ non-CSCs went apoptosis. The results of flow cytometric analysis are presented in Figures 4 and 5.

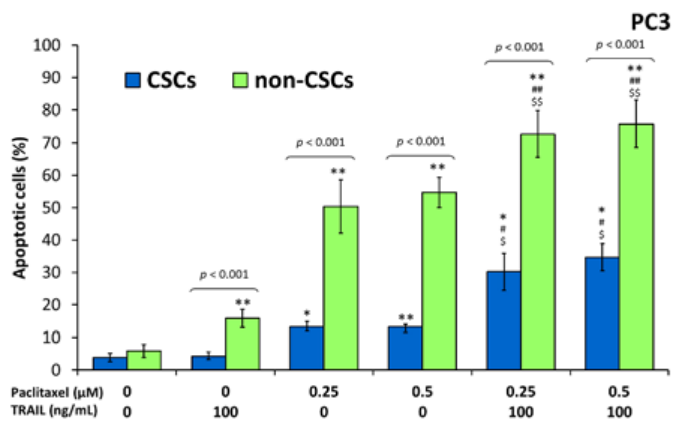

(a)

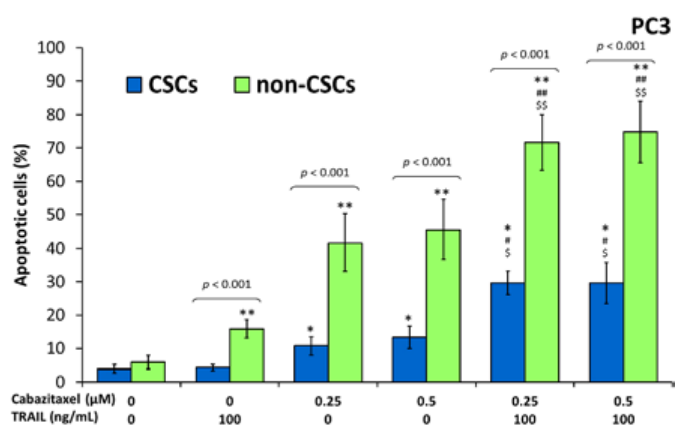

(c)

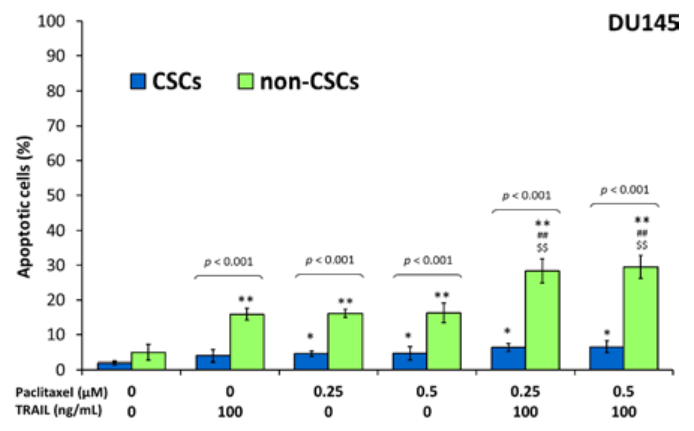

(b)

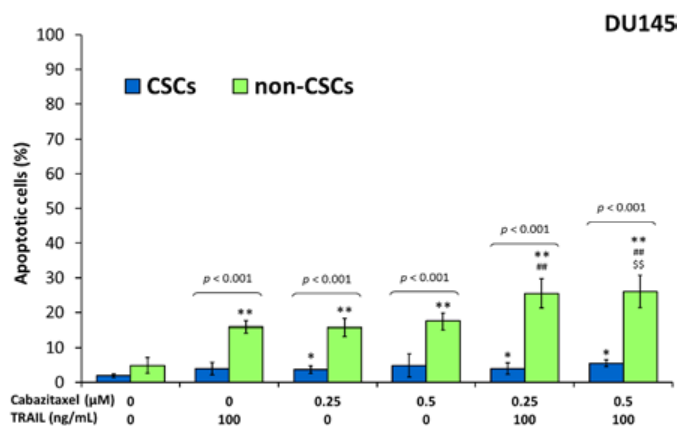

(d)

Figure 4. Cont. 


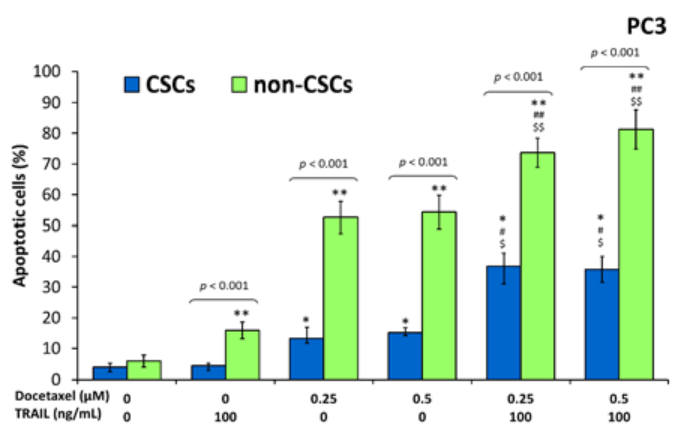

(e)

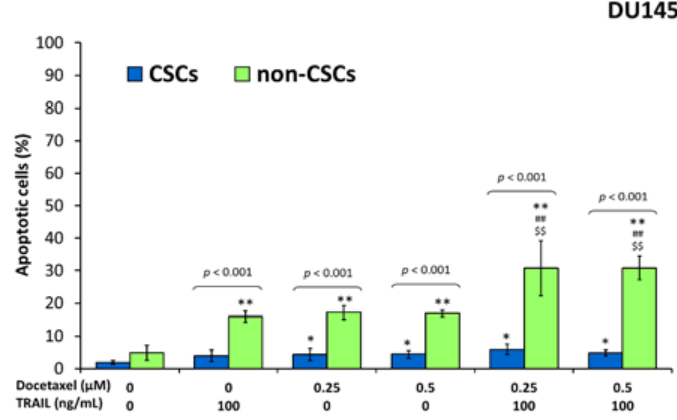

(f)

Figure 4. Apoptotic effect of TRAIL $(100 \mathrm{ng} / \mathrm{mL})$ in combination with paclitaxel, cabazitaxel and docetaxel in CSCs and non-CSCs subpopulations within DU145 and PC3 prostate cancer cells. The values represent mean $\pm \operatorname{SD}(n=6)$. Within CSCs subpopulation: ${ }^{*} p<0.05$, significantly different from the respective control; $\# p<0.05$, significantly different from TRAIL alone. $\$ p<0.05$, significantly different from respective taxane alone. Within non-CSCs subpopulation: ${ }^{* *} p<0.05$, significantly different from the respective control; \#\# $p<0.05$, significantly different from TRAIL alone. $\$ \$ p<0.05$, significantly different from respective taxane alone. (a) Apoptotic effect of TRAIL $(100 \mathrm{ng} / \mathrm{mL})$ in combination with paclitaxel, within CSCs and non-CSCs subpopulations in PC3 prostate cancer cells; (b) Apoptotic effect of TRAIL (100 ng/mL) in combination with paclitaxel, within CSCs and non-CSCs subpopulations in DU145 prostate cancer cells; (c) Apoptotic effect of TRAIL (100 ng/mL) in combination with cabazitaxel, within CSCs and non-CSCs subpopulations in PC3 prostate cancer cells; (d) Apoptotic effect of TRAIL (100 ng/mL) in combination with cabazitaxel, within CSCs and non-CSCs subpopulations in DU145 prostate cancer cells; (e) Apoptotic effect of TRAIL (100 ng/mL) in combination with docetaxel, within CSCs and non-CSCs subpopulations in PC3 prostate cancer cells; (f) Apoptotic effect of TRAIL (100 ng/mL) in combination with docetaxel, within CSCs and non-CSCs subpopulations in DU145 prostate cancer cells. 
Population

$\square$ CsCs

non-CSCs
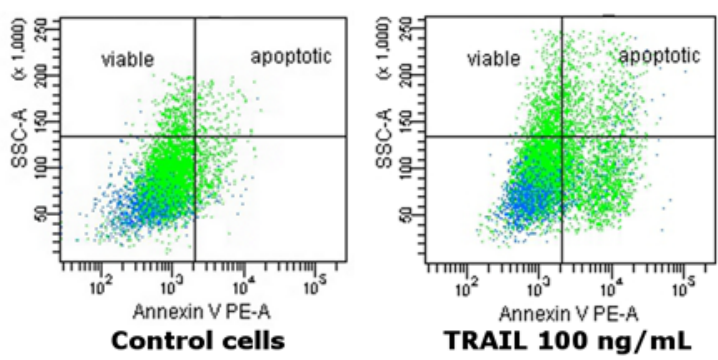

PC3
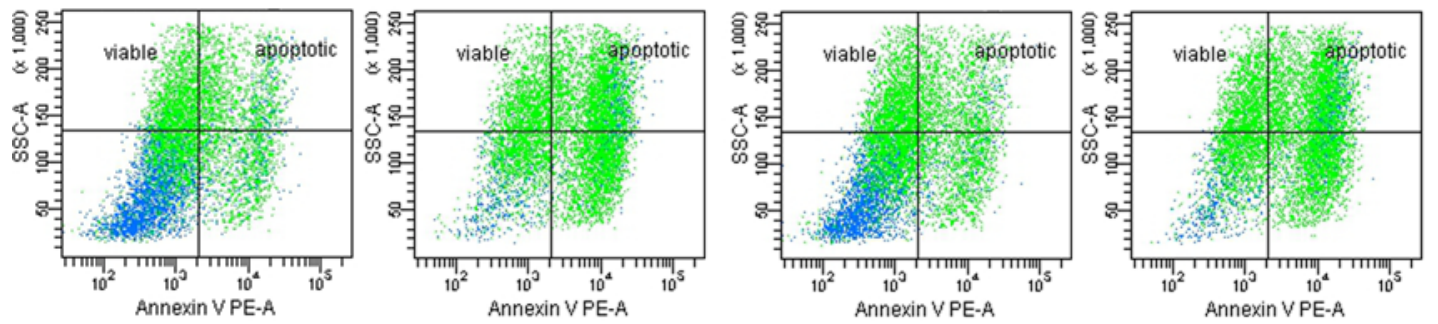

Paclitaxel $0.25 \mu \mathrm{M}$

Paclitaxel $0.25 \mu \mathrm{M}$ +TRAIL $100 \mathrm{ng} / \mathrm{mL}$
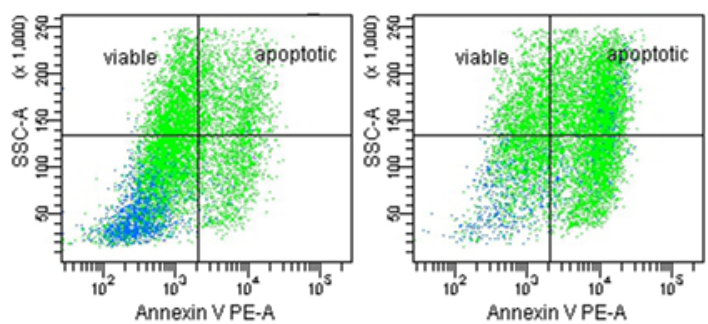

Cabazitaxel $0.25 \mu \mathrm{M}$ +TRAIL $100 \mathrm{ng} / \mathrm{mL}$
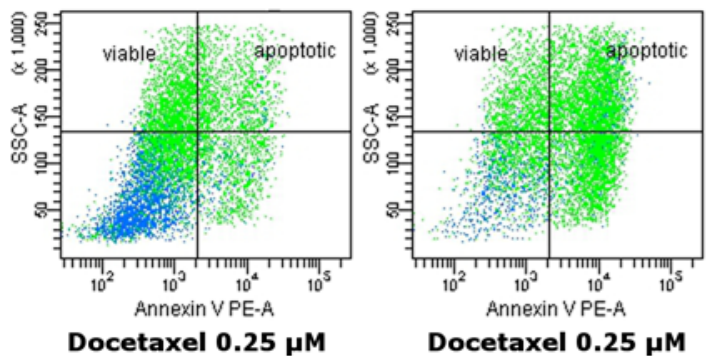

Docetaxel $0.25 \mu \mathrm{M}$ +TRAIL $100 \mathrm{ng} / \mathrm{mL}$

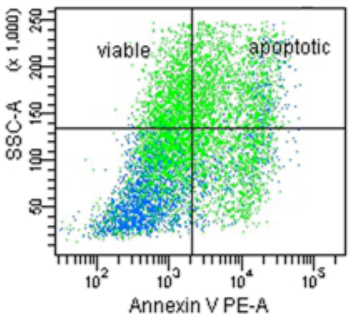

Paclitaxel $0.5 \mu \mathrm{M}$ +TRAIL $100 \mathrm{ng} / \mathrm{mL}$

Docetaxel $0.25 \mu \mathrm{M}$

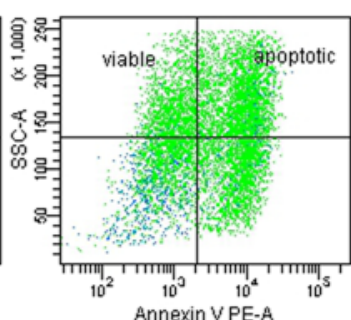

Cabazitaxel $0.5 \mu \mathrm{M}$

Cabazitaxel $0.5 \mu \mathrm{M}$ +TRAIL $100 \mathrm{ng} / \mathrm{mL}$
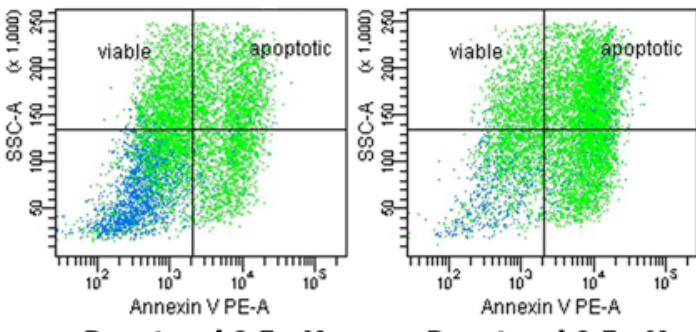

Docetaxel $0.5 \mu \mathrm{M}$

Docetaxel $0.5 \mu \mathrm{M}$ +TRAIL $100 \mathrm{ng} / \mathrm{mL}$

(a)

Figure 5. Cont. 

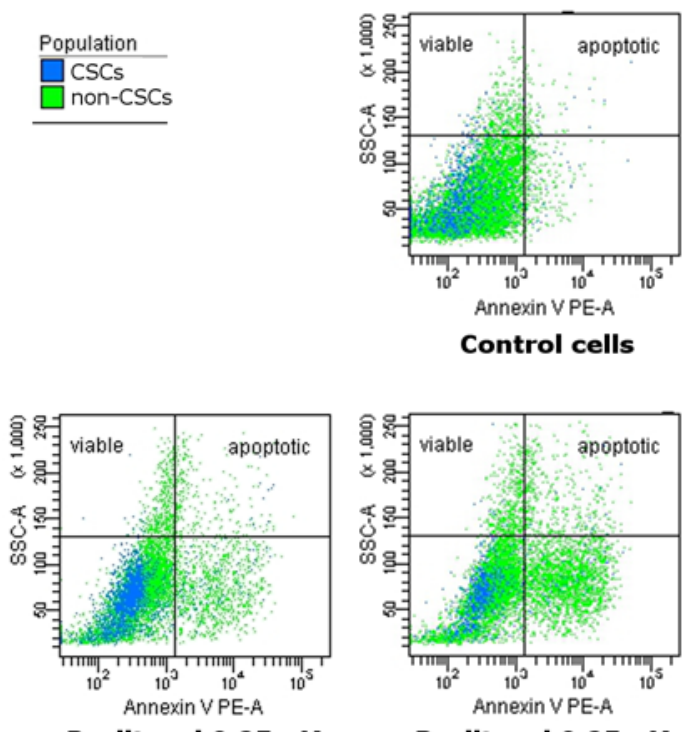

Paclitaxel $0.25 \mu \mathrm{M}$

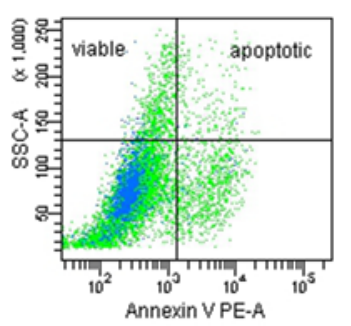

Cabazitaxel $0.25 \mu \mathrm{M}$

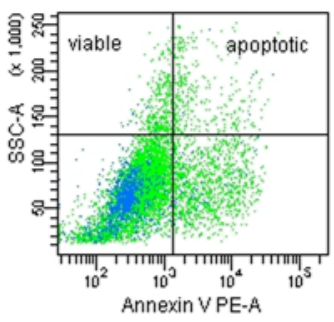

Docetaxel $0.25 \mu \mathrm{M}$

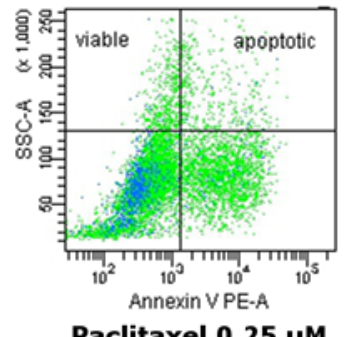

$0.25 \mu \mathrm{M}$ +TRAIL $100 \mathrm{ng} / \mathrm{mL}$

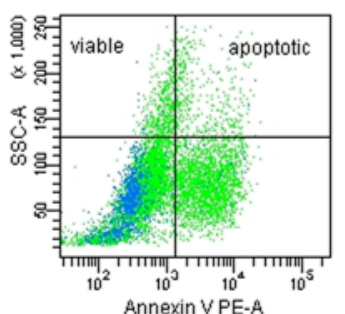

Cabazitaxel $0.25 \mu \mathrm{M}$ +TRAIL $100 \mathrm{ng} / \mathrm{mL}$

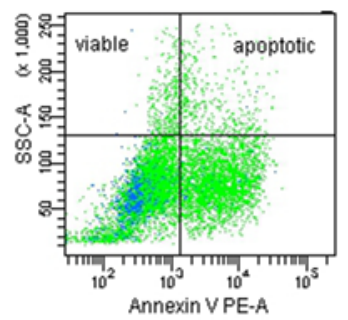

Docetaxel $0.25 \mu \mathrm{M}$ +TRAIL $100 \mathrm{ng} / \mathrm{mL}$
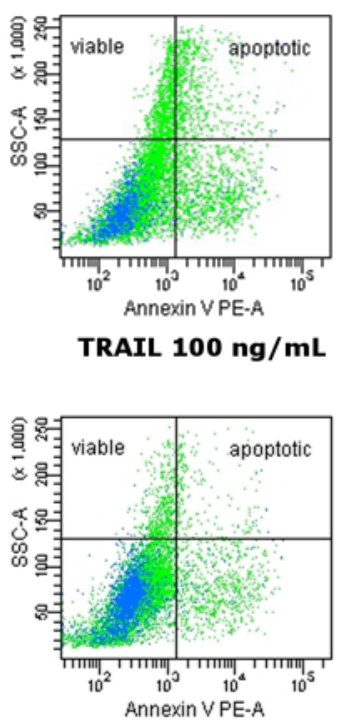

Paclitaxel $0.5 \mu \mathrm{M}$

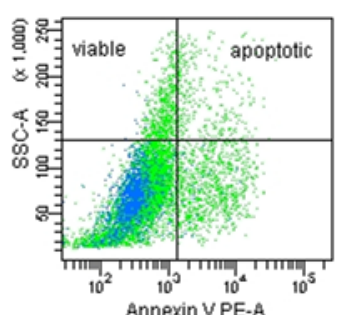

Cabazitaxel 0.5 нM

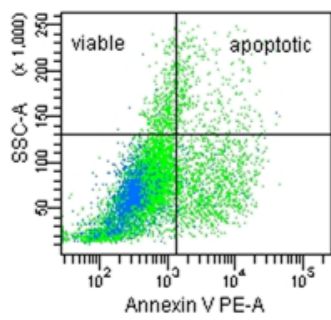

Docetaxel $0.5 \mu \mathrm{M}$

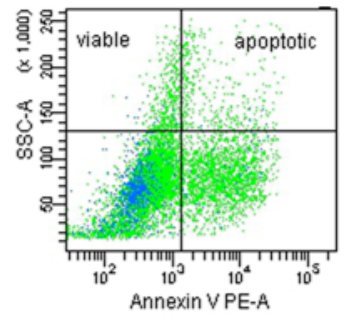

Paclitaxel $0.5 \mu \mathrm{M}$ +TRAIL $100 \mathrm{ng} / \mathrm{mL}$

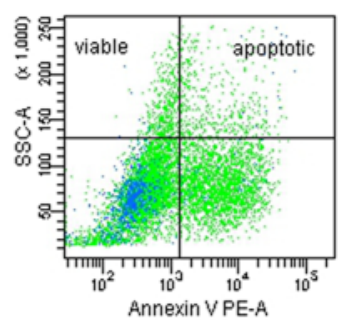

Cabazitaxel $0.5 \mu \mathrm{M}$ + TRAIL $100 \mathrm{ng} / \mathrm{mL}$

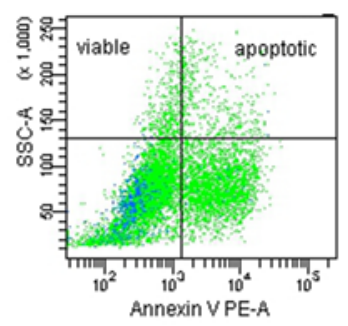

Docetaxel $0.5 \mu \mathrm{M}$

+TRAIL $100 \mathrm{ng} / \mathrm{mL}$

(b)

Figure 5. Apoptotic effect of TRAIL (100 ng/mL) in combination with paclitaxel, cabazitaxel and docetaxel on CSCs and non-CSCs subpopulations within: PC3 (a) and DU145 (b) prostate cancer cells. Cells were incubated with anti-CD24 FITC-labeled, anti-CD44 APC-labeled antibodies and Annexin V-PE labeled. CSCs marked as blue, non-CSCs marked as green. Viable cells are located on the left site of the dot plot and apoptotic cells on the right site of the dot plot.

2.9. CD44+/CD24-Cancer Stem Cell Number in DU145 and PC3 Cell Lines after the Treatment of TRAIL and/or Paclitaxel, Cabazitaxel, Docetaxel

Our results showed that combined treatment with TRAIL and taxanes changed percentage of CSCs in both analyzed prostate cancer cell lines compared to TRAIL or taxanes alone.

In the control sample of PC3 cells, the CSCs subpopulation was $11.4 \% \pm 1.9 \%$, and after the treatment with $100 \mathrm{ng} / \mathrm{mL}$ TRAIL, $13.7 \% \pm 4.4 \%$. Exposure to $0.25 \mu \mathrm{M}$ paclitaxel caused a significant increase to $25.5 \% \pm 3.3 \%$, and $0.5 \mu \mathrm{M}$ paclitaxel to $26.6 \% \pm 4.1 \%$ of CSCs subpopulation. However, the co-treatment of PC3 cancer cells with TRAIL at the concentration of $100 \mathrm{ng} / \mathrm{mL}$ and paclitaxel at the 
concentrations of $0.25 \mu \mathrm{M}$ and $0.5 \mu \mathrm{M}$ decreased the percentage of CSCs, respectively, to $6.3 \% \pm 0.7 \%$ and $6.2 \% \pm 0.7 \%$. After exposure to cabazitaxel alone, at the concentrations of $0.25 \mu \mathrm{M}$ and $0.5 \mu \mathrm{M}$, CSCs percentage increased, respectively, to $20.6 \% \pm 3.3 \%$ and $22.0 \% \pm 4.1 \%$. The co-treatment with TRAIL at the concentration of $100 \mathrm{ng} / \mathrm{mL}$ and cabazitaxel at the concentrations of $0.25 \mu \mathrm{M}$ and $0.5 \mu \mathrm{M}$, decreased the percentage of CSCs, respectively, to $6.8 \% \pm 0.7 \%$ and $5.5 \% \pm 0.6 \%$. Eventually, the treatment of docetaxel at the concentrations of $0.25 \mu \mathrm{M}$ and $0.5 \mu \mathrm{M}$ also caused a significant increase in CSCs number, respectively, to $21.3 \% \pm 2.5 \%$ and $25.0 \% \pm 3.5 \%$. The co-treatment with TRAIL at the concentration of $100 \mathrm{ng} / \mathrm{mL}$ and docetaxel at the concentrations of $0.25 \mu \mathrm{M}$ and $0.5 \mu \mathrm{M}$ decreased the percentage of CSCs, respectively, to $7.9 \% \pm 0.9 \%$ and $6.5 \% \pm 0.5 \%$. The described effect of TRAIL and/or paclitaxel, cabazitaxel and docetaxel on CSCs number in PC3 prostate cancer cells is presented in Figure 6a.

In the DU145 cell line, the CSCs subpopulation was $12.6 \% \pm 0.9 \%$ and after the treatment with $100 \mathrm{ng} / \mathrm{mL}$ TRAIL, $16.8 \% \pm 3.3 \%$. Exposure to $0.25 \mu \mathrm{M}$ and $0.5 \mu \mathrm{M}$ paclitaxel changed the CSCs number, respectively, to $15.4 \% \pm 2.7 \%$, and $18.1 \% \pm 4.1 \%$. On the other hand, the co-treatment of DU145 cancer cells with TRAIL at the concentration of $100 \mathrm{ng} / \mathrm{mL}$ and paclitaxel at the concentrations of $0.25 \mu \mathrm{M}$ and $0.5 \mu \mathrm{M}$ decreased the percentage of CSCs to $9.1 \% \pm 0.6 \%$ and $9.0 \% \pm 1.0 \%$, respectively. Cabazitaxel alone, at the concentrations of $0.25 \mu \mathrm{M}$ and $0.5 \mu \mathrm{M}$, changed CSCs percentage respectively to $12.0 \% \pm 4.1 \%$ and $13.8 \% \pm 2.8 \%$. However, the co-treatment with TRAIL at the concentration of $100 \mathrm{ng} / \mathrm{mL}$ and cabazitaxel at the concentrations of $0.25 \mu \mathrm{M}$ and $0.5 \mu \mathrm{M}$, decreased the percentage of CSCs, respectively, to $9.7 \% \pm 2.6 \%$ and $9.5 \% \pm 0.5 \%$. Eventually, the treatment of docetaxel at the concentrations $0.25 \mu \mathrm{M}$ and $0.5 \mu \mathrm{M}$ caused a slight decrease in CSCs number, respectively to $11.3 \% \pm 3.3 \%$ and $11.1 \% \pm 2.9 \%$. Interestingly, the co-treatment with TRAIL at the concentration of $100 \mathrm{ng} / \mathrm{mL}$ and docetaxel at the concentrations of $0.25 \mu \mathrm{M}$ and $0.5 \mu \mathrm{M}$ significantly decreased the percentage of CSCs, respectively, to $7.2 \% \pm 2.5 \%$ and $6.95 \% \pm 2.6 \%$. The described effect of TRAIL and/or paclitaxel, cabazitaxel and docetaxel on CSCs number in DU145 prostate cancer cells is presented in Figure 6b.

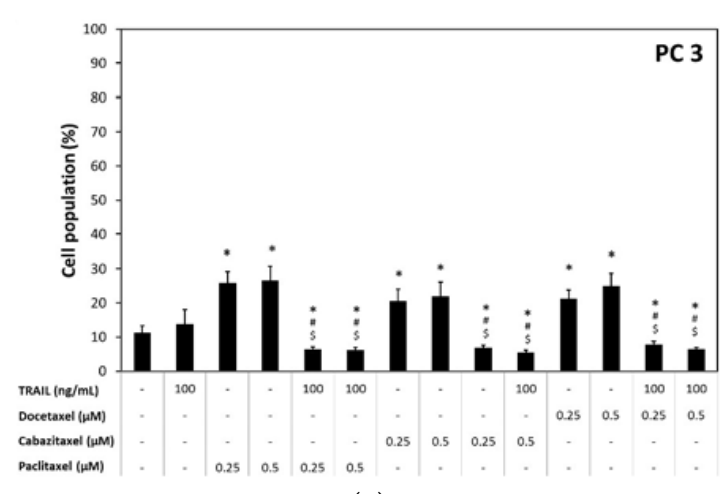

(a)

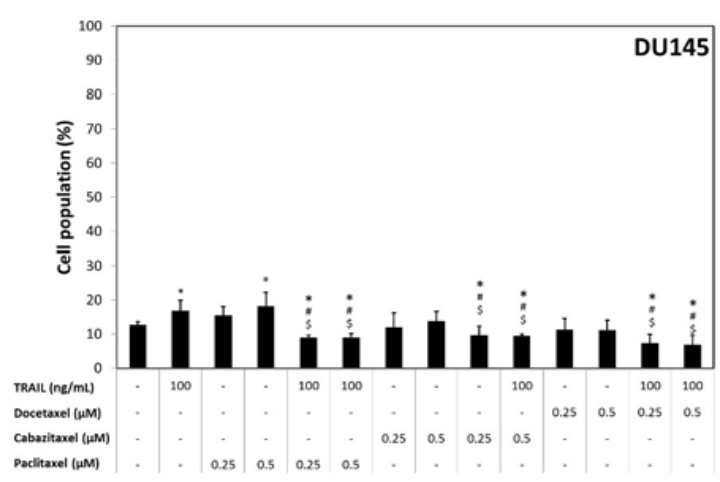

(b)

Figure 6. Effect of TRAIL (100 ng/mL) in combination with paclitaxel, cabazitaxel and docetaxel on CSCs number in DU145 and PC3 prostate cancer cells. ${ }^{*} p<0.05$, significantly different from the respective control; \# $p<0.05$, significantly different from TRAIL alone; $\$ p<0.05$, significantly different from respective taxane alone. (a) CSCs number in PC3 prostate cancer cells after incubation with TRAIL (100 ng/mL) and/or paclitaxel, cabazitaxel, docetaxel; (b) CSCs number in DU145 prostate cancer cells after incubation with TRAIL (100 ng/mL) and/or paclitaxel, cabazitaxel, docetaxel.

\subsection{Expression of TRAIL-Receptors (R1, R2, R3 and R4) on the Surface of PC3 and DU145 Prostate Cancer Cells}

The sensitivity of cancer cell to TRAIL is connected with the expression of death receptors TRAIL-R1/DR4 and TRAIL-R2/DR5. We have analyzed by flow cytometry the expression of TRAIL-R1/DR4 and TRAIL-R2/DR5 on the surface of CSCs and compared it to non-CSCs 
subpopulation. In PC3 and DU145 cells, the fluorescence signal corresponding to TRAIL-R1 expression was very dim. In DU145 cells, our results demonstrated no significant difference between the populations of CSCs and non-CSCs, while, in PC3 cells, there was only slight difference. On the other hand, the signal corresponding to TRAIL-R2 expression was much brighter. Furthermore, we have detected that TRAIL-R2 expression in non-CSCs subpopulation was significantly higher than in CSCs for the PC3 cancer cells. The results of the experiment are presented in Figure 7.
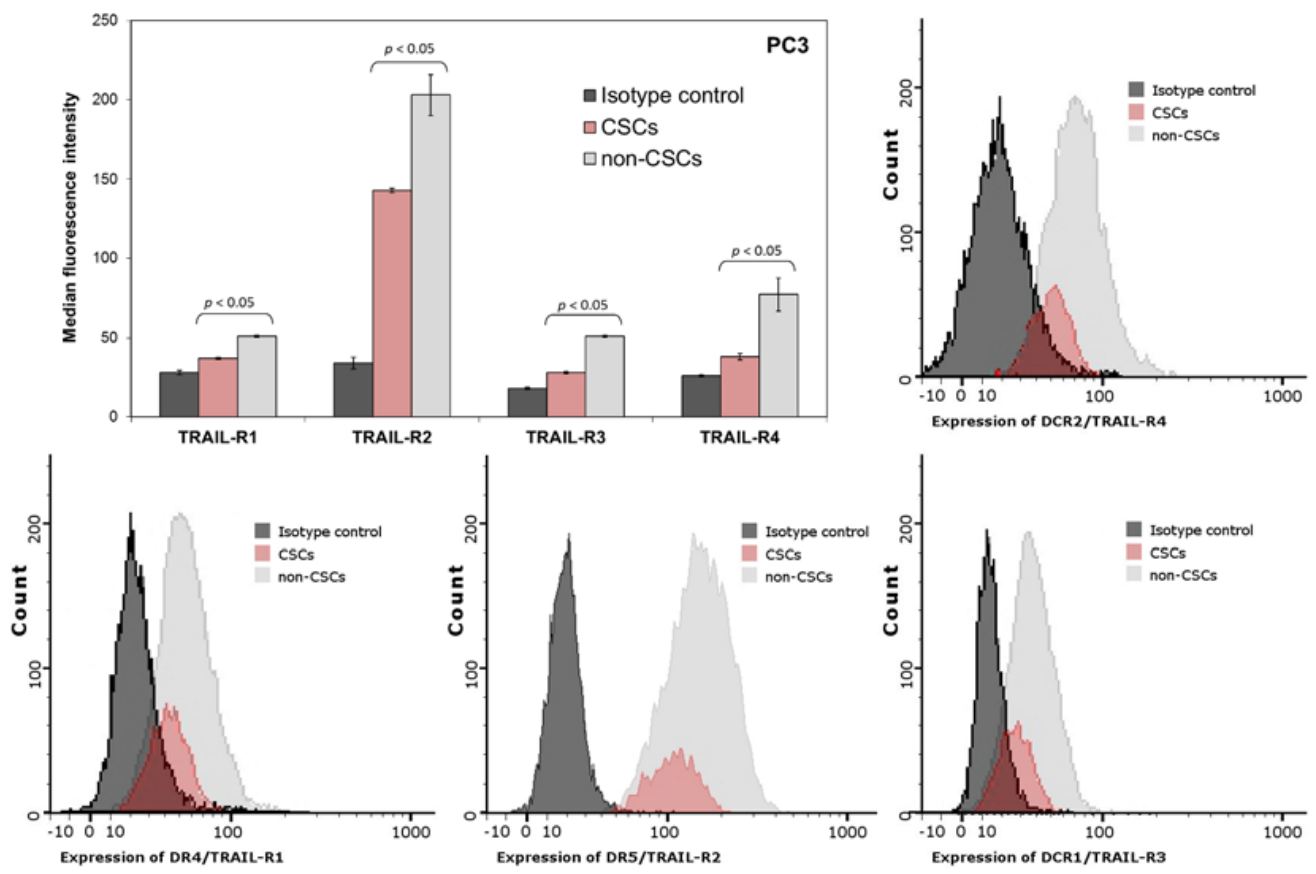

(a)
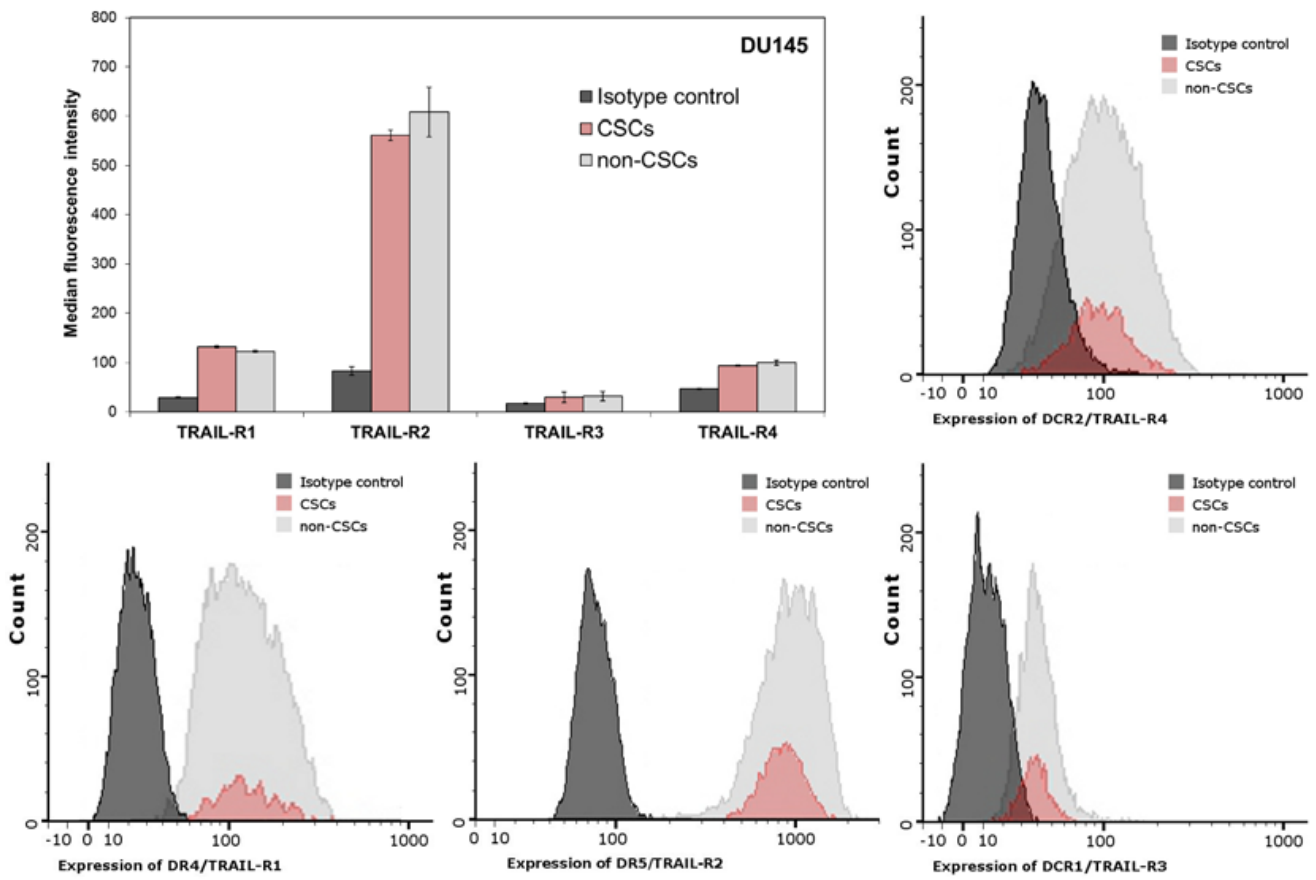

(b)

Figure 7. Expression of TRAIL-Receptors (R1, R2, R3 and R4) on the Surface of CSCs and non-CSCs subpopulations within: PC3 (a); and DU145 (b) prostate cancer cells. The dark grey histogram shows isotype control, red corresponds to CSCs, and light grey histogram shows non-CSCs. 
We have also analyzed the expression of decoy receptors TRAIL-R3 and TRAIL-R4 on the surface of CSCs and the non-CSCs subpopulation. The expression of decoy receptors in PC 3 and DU145 cancer cells was very low and probably irrelevant.

2.11. Effects of Paclitaxel, Cabazitaxel or Docetaxel on TRAIL-Receptors $(R 1, R 2)$ Expression on the Surface of PC3 and DU145 Prostate Cancer Cells

We have shown that paclitaxel, cabazitaxel and docetaxel enhance TRAIL-mediated apoptosis, therefore the next step was to determine if this compounds increase the expression of death domain-containing transmembrane receptors: TRAIL-R1 (DR4) and TRAIL-R2 (DR5). In PC3 and DU145 cells, flow cytometry was employed to show that the fluorescence signal corresponding to TRAIL-R1 expression was again very dim. The median values of fluorescence intensity have not been changed after the exposure to analyzed taxanes (data not shown). On the other hand, the TRAIL-R2 (DR5) is upregulated on the surface of PC3 cells after the treatment with taxanes. Both subpopulations, CSCs and non-CSCs, have elevated expression of this receptor following the treatment with paclitaxel, cabazitaxel and docetaxel. However, on the surface of DU145, the expression of TRAIL-R2 (DR5) is almost unchanged after the exposition to paclitaxel, cabazitaxel and docetaxel. The described effect of paclitaxel, cabazitaxel and docetaxel on TRAIL-R2 expression on the surface of PC3 and DU145 prostate cancer cells is presented in Figure 8.
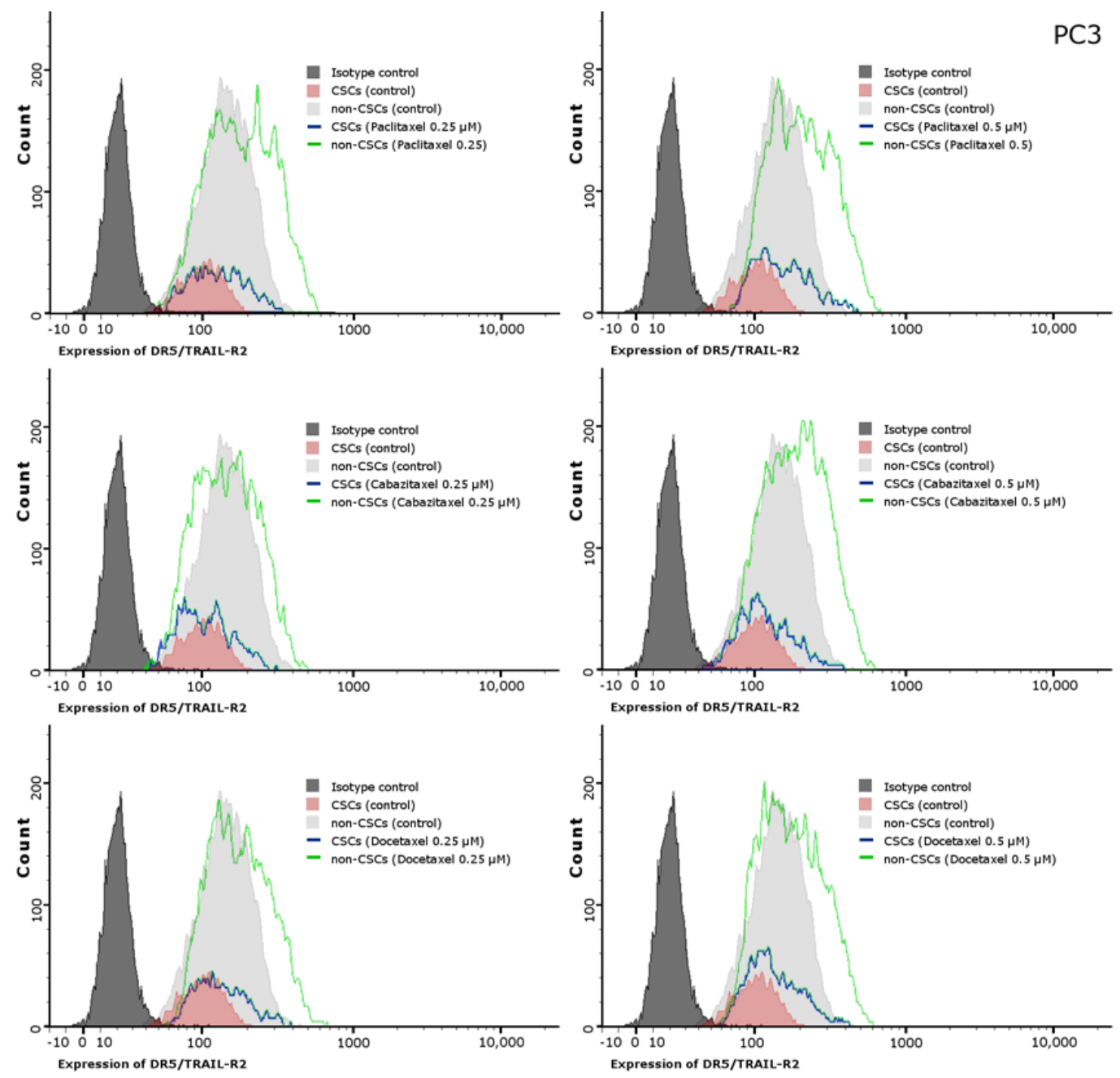

(a)

Figure 8. Cont. 
DU145
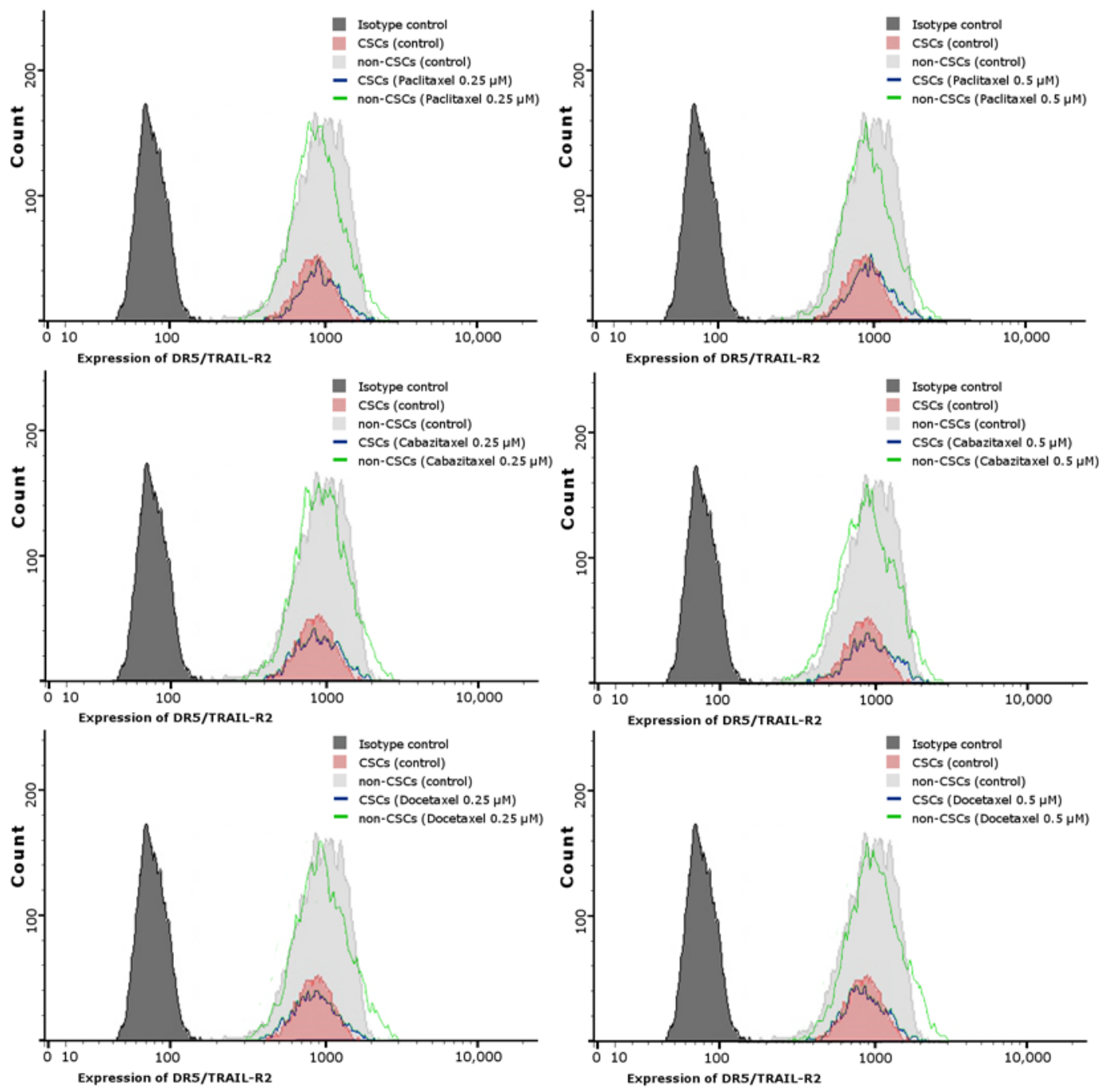

(b)

Figure 8. Effects of paclitaxel, cabazitaxel or docetaxel on expression of TRAIL-R2 on the surface of CSCs and non-CSCs subpopulations within: PC3 (a); and DU145 (b) prostate cancer cells. The dark grey histogram shows isotype control, red corresponds to CSCs, light grey histogram shows non-CSCs, blue line shows CSCs after treatment with adequate taxane, and green line corresponds non-CSCs treated with adequate taxane.

\section{Discussion}

Prostate cancer stem cells (CSCs) are a small subpopulation of cancer cells, which possess stem-like properties, such as the ability to self-renew, and are capable of driving tumor growth and metastasis $[4,35]$. These cells are also more resistant to hormonotherapy, radiotherapy and chemotherapy than differentiated daughter cells. Numerous studies and clinical evidence suggest an increased CSCs in tumor mass may contribute to the failure of the therapy. Current therapeutic protocols often lead to the disease progression, because they target the bulk of fast growing cancer cells but not undifferentiated, slow cycling cancer stem cells [36-38].

Many potential stem cells markers have been identified in prostate, however the CD44+/CD24cells have been associated with the prostate cancer stem cells which possess the ability to grow as nonadherent spheres in serum replacement medium and a potential to form tumors in NOD/SCID 
mice. It has been shown that CD44 expression can be connected with the increased clonogenic and metastatic potential $[9,14]$.

New therapeutics introduced to prostate cancer treatment have greatly improved the overall survival of the patients, however the relapse of chemoresistant tumor remains the major problem. Generally, most therapeutics only target the dividing tumor cells, therefore the CSCs population remain intact. Consequently, the expansion of CSCs population results in rising drug resistance among the cells constituting the tumor mass $[7,8,30]$.

Acquired resistance to taxane based chemotherapy remains a major consideration for patients who show an initial therapeutic benefits from taxane treatment. The stem-cells directed therapy could sensitize these cells to anticancer drugs $[39,40]$.

TRAIL (tumor necrosis factor-related apoptosis inducing ligand) is a promising anti-cancer agent because of its selectivity. It induces apoptosis in cancer cells but not in normal cells. In our research, we examined if treatment with one of the three different taxanes can enhance apoptosis induced by TRAIL. We observed that paclitaxel, cabazitaxel and docetaxel in combination with TRAIL effectively induce apoptosis in PC3 cells. In DU145 cells, the apoptosis was less intense but also significant. The apoptotic cell death induced by taxanes and TRAIL alone was significantly lower in both cell lines. Our results correspond to other previous observations that chemotherapeutic agents can enhance TRAIL-induced apoptosis in human cancers such as breast cancer [41,42], squamous carcinoma [43], colon cancer [44], renal carcinoma, bladder cancer, lung cancer and prostate cancer [45,46]. Taxanes, such as paclitaxel, in combination with TRAIL have been shown to induce apoptosis of 86M1 small cell lung cancer cells [47], resistant gastric cancer cells [48] and PC3, DU145 and LNCaP prostate cancer cells [49]. Moreover, pretreatment of docetaxel have been shown to enhance apoptosis mediated by TRAIL in prostate cancer cells [50].

Furthermore, we examined using flow cytometry and test with Annexin V the apoptotic cell death in two subopulations, CSCs and non-CSCs, gated among the PC 3 and DU145 cells. In both cell lines, CSCs were much more resistant to apoptotic effect of TRAIL, paclitaxel, cabazitaxel or docetaxel used alone. The co-treatment with taxanes and TRAIL enhanced the apoptotic cell death in both subpopulations (CSCs and non-CSCs) in PC3 prostate cancer cells. While in DU145 cells the co-treatment with taxanes and TRAIL enhanced significantly apoptosis only in non-CSCs subpopulation.

We also examined the incidence of CSCs in PC3 and DU145 cancer stem cells. In both cell lines, CSCs subpopulation comprised about 10-13\% of all cells. Interestingly, PC3 and DU145 cells after the treatment with each taxane alone, have a larger proportion of CSCs (up to $26 \%$ in PC3 and up to $18 \%$ in DU145), whereas the treatment with paclitaxel, cabazitaxel or docetaxel in combination with TRAIL resulted in reduction of CSCs frequency to the level of 5\% in PC 3 cells and 7\% in DU145 cells. This result may indicate that paclitaxel, cabazitaxel and docetaxel kills preferentially the non-CSCs cells whereas CSCs subpopulation is more resistant. However using a combination of agents: paclitaxel, cabazitaxel or docetaxel and TRAIL have an opposite effect- - the number of CSCs in both cell lines were reduced. These data suggest that co-treatment with taxane and TRAIL can enhance the CSCs subpopulation cell death. Therefore, the percentage of CSCs decreases.

Cells with stem-like properties have been studied recently and associated with unfavorable prognosis and aggressive disease. In breast carcinoma CD44 positive and CD24 negative cells have been found in distant metastasis, therefore this phenotype is connected with a relapse after surgical resection [51,52]. PC3 and DU145 cell lines have been derived from the prostate cancer patients with a distinct metastasis (to the lymph node and the brain). This explains the occurrence of the CD44+/CD24- cells in both cell lines.

Conventional therapies in the cancer treatment kill the rapidly dividing cells resulting in tumor withdrawal. However, the CSCs which are more quiescent and resistant to anti-cancer agents, differentiate into new tumor cells and are responsible for tumor relapse. CSCs express high levels of ATP-binding cassette drug transporters [53,54], cell adhesion molecules (CD44) [55], or cell survival 
proteins which are responsible for their chemoresistance [56]. Thus far, there have been only a few approaches to overcome this resistance and improve the efficiency of the chemotherapeutic drugs against CSCs population in the breast cancer, prostate cancer and ovary cancer cells $[57,58]$.

Interestingly, even naturally occurring compounds have been found to enhance the efficacy of chemotherapeutics. Green tea and a flavonoid quercetin enhanced the efficacy of docetaxel in LAPC-4-AI and PC-3 prostate cancer cells. Furthermore, the combination of this compound and docetaxel inhibited tumor cell invasion, colony formation and decreased the percentage of CSCs [59].

Taxanes are highly active anticancer drugs which have been shown to trigger apoptosis not only by intrinsic (mitochondrial) pathway but also extrinsic pathway (by induction of death receptors expression) $[47-49,60]$. It was discovered before, that treatment of prostate cancer cells with paclitaxel and TRAIL resulted in greater processing of caspase- -8 , Bid, procaspase- -9 and caspase- 3 , resulting in engagement of the mitochondrial pathway to apoptosis [49]. Hunter et al. discovered, that in non-small cell lung cancer cells treated with paclitaxel and TRAIL, the expression of pro-survival protein Bcl-xl, was down regulated. They also found out that after the treatment with paclitaxel and TRAIL, apoptosis inducing factor (AIF) was cleaved into mature form, then left the mitochondria and was translocated to the nucleus where it was able to initiate DNA degradation [47]. Finally, Li et al. showed that inhibition of MAPK was involved in paclitaxel-mediated sensitization to TRAIL in resistant gastric cancer cells [48]. Moreover, also docetaxel was shown to enhance TRAIL-induced apoptosis through caspase-8, caspase-9 and caspase-3 activation in different prostate cancer cell lines [50].

We have discovered that paclitaxel, cabazitaxel and docetaxel enhance TRAIL-mediated apoptosis especially in non-CSCs population. Next, we tried to determine if those compounds increase the expression of death receptors: TRAIL-R1 (DR4) and TRAIL-R2 (DR5). TRAIL-R1 expression was very low and did not change after taxanes treatment in both cell lines. Nevertheless, we discovered that TRAIL-R2 (DR5) expression was increased on the surface of PC3 cells treated with taxanes. In addition, we have observed that on the surface of CSCs TRAIL-R2 expression was lower compared to non-CSCs population. Furthermore, both subpopulations, CSCs and non-CSCs have elevated expression of this receptor following the treatment with paclitaxel, cabazitaxel and docetaxel in PC3 cells. The level of TRAIL-R2 expression in DU145 cells remained unchanged after treatment with taxanes, which could explain their resistance. The mechanism by which taxanes sensitizes prostate cancer cells to TRAIL-induced apoptosis is not clear and a further study are required to explain how these chemotherapeutics affect the apoptotic signaling pathways.

It has been demonstrated that chemotherapeutic agents can have an influence on TRAIL-R2-mediated apoptosis and cytotoxicity in various human solid cancer cells. It was proven that low concentrations of doxorubicin significantly increased TRAIL-R2 expression in human prostate, bladder, and lung cancer cells [46]. It was discovered that in human gastric cancer paclitaxel markedly enhanced TRAIL-induced apoptosis by activation of mitochondrial pathway, upregulation of TRAIL receptors and downregulation of anti-apoptotic proteins [48]. Eventually, it was revealed that docetaxel enhances TRAIL-mediated apoptosis due to upregulation of TRAIL-R2 in melanoma cells [61]. However, there is no published paper regarding CSCs population in prostate cancer and TRAIL-mediated apoptosis.

Presently, we can only speculate about mechanisms of apoptosis activation by different taxane derivatives and their cooperation with TRAIL. There is not enough evidence yet, and still many questions remain to be answered to understand the CSCs role in the chemoresistance of prostate cancer.

\section{Materials and Methods}

\subsection{Cell Lines}

Human prostate cancer DU145 and PC3 cell lines was purchased from DSMZ (Deutsche Sammlung von Mikroorganismen und Zellkulturen, Braunschweig, Germany). The DU145 cells were grown in RPMI-1640 medium. The PC3 cells were maintained in RPMI-1640 with the addition 
of Ham's medium. The media were supplemented with $10 \%$ heat-inactivated fetal bovine serum, $4 \mathrm{mM}$ L-glutamine, $100 \mathrm{U} / \mathrm{mL}$ penicillin and $100 \mu \mathrm{g} / \mathrm{mL}$ streptomycin. The cells were incubated at $37{ }^{\circ} \mathrm{C}$ in a humidified atmosphere of $5 \% \mathrm{CO}_{2}$. Reagents for cell culture were purchased from ATCC (American Type Culture Collection, Manassas, VA, USA).

\subsection{Reagents}

Soluble recombinant human TRAIL (rhsTRAIL) was obtained from PeproTech Inc. (Rocky Hill, NJ, USA). Semisynthetic paclitaxel and docetaxel were purchased from Sigma Aldrich Chemical Company (St. Louis, MO, USA). The purity of paclitaxel and docetaxel was $\geq 97 \%$ (HPLC). Cabazitaxel was purchased from LC Laboratories (Woburn, MA, USA). The purity of cabazitaxel was $\geq 99 \%$ (HPLC). Tested compounds were dissolved in DMSO (dimethyl sulfoxide) to obtain the working concentrations.

\subsection{Detection of Apoptotic and Necrotic Cell Death by Flow Cytometry}

Apoptosis was measured by flow cytometry using the Apoptosis-PE Kit with Annexin V (Becton Dickinson Biosciences, San Jose, CA, USA). Prostate cancer cells DU145 and PC3 $\left(5 \times 10^{4} / \mathrm{mL}\right)$ were seeded in 24-well plates for $24 \mathrm{~h}$ and then exposed to TRAIL in concentration of $100 \mathrm{ng} / \mathrm{mL}$ and/or one of the taxanes (paclitaxel, docetaxel or cabazitaxel) for $48 \mathrm{~h}$. After this time the cells were harvested using trypsin and ethylenediaminetetracetic acid (EDTA) and then washed twice with phosphate-buffered saline (PBS) solution and resuspended in $1 \times$ Binding Buffer $(100 \mu \mathrm{L})$. Then the cell suspension was incubated with Annexin V-PE $(5 \mu \mathrm{L})$ and 7-AAD $(5 \mu \mathrm{L})$ for $10 \mathrm{~min}$ at $4^{\circ} \mathrm{C}$ in the dark. After this time $400 \mu \mathrm{L}$ of $1 \times$ Binding Buffer was added to each tube. The cells were analyzed by flow cytometry (LSR II, Becton Dickinson Biosciences, San Jose, CA, USA) within $1 \mathrm{~h}$.

\subsection{Lactate Dehydrogenase Release Assay}

Lactate dehydrogenase (LDH) activity was measured in culture supernatants with an enzymatic assay, based on the conversion of tetrazolium salt into a red formazan product. Reagents were purchased from Roche Diagnostics GmbH (Mannheim, Germany). DU145 and PC3 cells were treated with various concentrations of one of the taxanes (paclitaxel, docetaxel or cabazitaxel) for the specified period of time. Then, supernatant was removed, and the LDH release from the cells to the culture medium was measured by the spectrophotometer at $490 \mathrm{~nm}$. Additionally, control cells were treated with $1 \%$ Triton X-100 for $10 \mathrm{~min}$ (room temperature) to obtain maximal LDH release. The percentage of the necrotic cells was calculated according to a formula:

$$
\begin{gathered}
\% \text { Cytotoxicity }=(\text { Compound-treated LDH Release }- \text { Spontaneous LDH Release } / \\
\text { Maximal Release }- \text { Spontaneous LDH Release }) \times 100
\end{gathered}
$$

\subsection{Detection of CD44+/CD24- Cancer Stem Cells by Flow Cytometry}

CD44+/CD24- subpopulation of cancer stem cells was labeled using anti-CD24-FITC and anti-CD44-APC monoclonal antibodies (Becton Dickinson Biosciences, San Jose, CA, USA). Prostate cancer cells DU145 and PC $3\left(5 \times 10^{4} / \mathrm{mL}\right)$ were seeded in 24 -well plates for $24 \mathrm{~h}$ and then exposed to TRAIL in concentration of $100 \mathrm{ng} / \mathrm{mL}$ and/or one of the taxanes (paclitaxel, docetaxel or cabazitaxel) for $48 \mathrm{~h}$. After this time the cells were harvested using trypsin and ethylenediaminetetracetic acid (EDTA) and then washed twice with phosphate-buffered saline (PBS) solution and resuspended in PharmingenStain Buffer with BSA (100 $\mu \mathrm{L})$ (Becton Dickinson Biosciences, San Jose, CA, USA). Then the cell suspension was incubated with anti-CD24-FITC $(20 \mu \mathrm{L})$ and anti-CD44-APC $(20 \mu \mathrm{L})$ monoclonal antibodies for 20 minutes in the dark. Cells in separate tubes treated with mouse IgG1 APC and IgG2a FITC monoclonal antibody constituted the isotype controls (Becton Dickinson Biosciences, San Jose, CA, USA). After incubation, $400 \mu \mathrm{L}$ of PharmingenStain Buffer (BSA) was added to each tube. 
Finally, the cells were analyzed by flow cytometry (LSR II, Becton Dickinson Biosciences, San Jose, CA, USA) within $1 \mathrm{~h}$.

\subsection{Detection of Apoptotic Cell Death by Flow Cytometry in the Subpopulations of Cells in DU145 and PC3 Prostate Cancer Cell Lines}

Apoptosis was measured by flow cytometry using the Apoptosis-PE Kit with Annexin V. Subpopulation of cancer stem cells was labeled as CD44+/CD24- using anti-CD24-FITC and anti-CD44-APC monoclonal antibodies (Becton Dickinson Biosciences, San Jose, CA, USA). Prostate cancer cells DU145 and PC3 $\left(5 \times 10^{4} / \mathrm{mL}\right)$ were seeded in 24-well plates for $24 \mathrm{~h}$ and then exposed to TRAIL in concentration of $100 \mathrm{ng} / \mathrm{mL}$ and/or one of the taxanes (paclitaxel, docetaxel or cabazitaxel) for $48 \mathrm{~h}$. After this time the cells were harvested using trypsin and ethylenediaminetetracetic acid (EDTA), then washed twice with phosphate-buffered saline (PBS) solution and resuspended in $1 \times$ Binding Buffer $(100 \mu \mathrm{L})$. The cell suspension was incubated with Annexin V-PE $(5 \mu \mathrm{L})$, anti-CD24-FITC $(20 \mu \mathrm{L})$ and anti-CD44-APC $(20 \mu \mathrm{L})$ monoclonal antibodies for $20 \mathrm{~min}$ at $4{ }^{\circ} \mathrm{C}$ in the dark. After this time $400 \mu \mathrm{L}$ of $1 \times$ Binding Buffer was added to each tube. The cells were analyzed by flow cytometry (LSR II, Becton Dickinson Biosciences, San Jose, CA, USA) within $1 \mathrm{~h}$.

\subsection{Analysis of Death Receptor Expression on the Cancer Cell Surface by Flow Cytometry}

The expression of four death receptors (DR4/TRAIL R1, DR5/TRAIL R2, TRAIL R3 and TRAIL R4) was determined using appropriate monoclonal antibodies conjugated with phycoerythrin (PE) or peridinin chlorophyll (PerCP) purchased from R\&D Systems (Minneapolis, MA, USA). Prostate cancer cells DU145 and PC3 $\left(5 \times 10^{4} / \mathrm{mL}\right)$ were seeded in 24-well plates for $24 \mathrm{~h}$ and then exposed to various concentrations of the taxanes (paclitaxel, docetaxel or cabazitaxel) for $48 \mathrm{~h}$. After this time the cells were harvested using Accutase Solution (PAN-Biotech $\mathrm{GmbH}$, Aidenbach, Germany). The cells were further incubated in medium for $6 \mathrm{~h}$ on a rocker platform to enable regeneration of the receptors. The cells were washed with PBS (with $0.5 \%$ BSA) and then Fc-blocked ( $1 \mu \mathrm{g}$ IgG $/ 10^{6}$ cells) for $15 \mathrm{~min}$ at room temperature. After this time an appropriate conjugated antibody was added (10 $\mu \mathrm{L}$ of anti-TRAIL R-1, anti-TRAIL R-2, anti-TRAIL R-3 or anti-TRAIL R-4 for $4 \times 10^{5}$ cells). Then the cells were incubated in $4{ }^{\circ} \mathrm{C}$ for $20 \mathrm{~min}$. After this time to each tube additional antibodies were added: anti-CD24-FITC and anti-CD44-APC (Becton Dickinson Biosciences, San Jose, CA, USA). The cells were incubated in $4{ }^{\circ} \mathrm{C}$ for another $20 \mathrm{~min}$. After the incubation the cells were washed with PBS and finally analyzed by flow cytometry. Cells in separate tubes treated with appropriate mouse IgG (IgG1, IgG2a or IgG2b) monoclonal antibody conjugated with PE, PerCP, APC or FITC constituted the isotype control. Anti-TRAIL-R isotype controls were purchased from R\&D Systems (Minneapolis, MA, USA) and anti-CD24 and anti-CD44 isotype controls from Becton Dickinson Biosciences (San Jose, CA, USA).

\subsection{Statistical analysis}

The results are presented as means \pm SD $(n=6)$. Statistical significance was evaluated using ANOVA or Student's $t$-test. $p<0.05$ was considered significant. For statistical calculation, StatSoft Statistic version 12 or Microsoft Excel 2010 was used.

Acknowledgments: This work was supported by a research grants KNW-1-039/K/6/I and KNW-1-037/K/7/I from the Medical University of Silesia in Katowice (Poland) and by the project "Silesian BIO-FARM Centre for Biotechnology, Bioengineering and Bioinformatics".

Author Contributions: Dagmara Jaworska and Ewelina Szliszka conceived and designed the experiments; Dagmara Jaworska performed the experiments; Dagmara Jaworska and Ewelina Szliszka analyzed the data; Dagmara Jaworska wrote the paper; and Ewelina Szliszka reviewed the manuscript.

Conflicts of Interest: The authors declare no conflict of interest. 


\section{Abbreviations}

$\begin{array}{ll}\text { CSC } & \text { cancer stem cell } \\ \text { TRAIL } & \text { tumor necrosis factor-related apoptosis-inducing ligand } \\ \text { PE } & \text { phycoerythrin } \\ \text { TRAIL-R } & \text { receptor of tumor necrosis factor-related apoptosis-inducing ligand } \\ \text { NOD/SCID } & \text { non-obese diabetic/severe combined immunodeficiency } \\ \text { TNF } & \text { tumor necrosis factor } \\ \text { DR } & \text { death receptor } \\ \text { CRPC } & \text { castration-resistant prostate cancer } \\ \text { FDA } & \text { food and drug administration } \\ \text { SD } & \text { standard deviation } \\ \text { LDH } & \text { lactate dehydrogenase } \\ \text { 7-AAD } & \text { 7-aminoactinomycin D } \\ \text { non-CSC } & \text { non-cancer stem cell } \\ \text { FITC } & \text { fluorescein isothiocyanate } \\ \text { APC } & \text { allophycocyanin } \\ \text { DCR } & \text { decoy receptor } \\ \text { ATP } & \text { adenosine triphosphate } \\ \text { AIF } & \text { apoptosis inducing factor } \\ \text { MAPK } & \text { mitogen-activated protein kinase } \\ \text { DSMZ } & \text { Deutsche Sammlung von Mikroorganismen und Zellkulturen } \\ \text { RPMI } & \text { Roswell Park Memorial Institute medium } \\ \text { ATCC } & \text { American Type Culture Collection } \\ \text { DMSO } & \text { dimethyl sulfoxide } \\ \text { EDTA } & \text { ethylenediaminetetracetic acid } \\ \text { PBS } & \text { phosphate-buffered saline } \\ \text { PerCP } & \text { peridinin chlorophyll } \\ \text { ANOVA } & \text { analysis of variance }\end{array}$

\section{References}

1. Miller, K.D.; Siegel, R.L.; Lin, C.C.; Mariotto, A.B.; Kramer, J.L.; Rowland, J.H.; Stein, K.D.; Alteri, R.; Jemal, A. Cancer treatment and survivorship statistics. CA Cancer J. Clin. 2016, 66, 271-289. [CrossRef] [PubMed]

2. Siegel, R.L.; Miller, K.D.; Jemal, A. Cancer statistics. CA Cancer J. Clin. 2015, 65, 5-29. [CrossRef] [PubMed]

3. Mokdad, A.H.; Dwyer-Lindgren, L.; Fitzmaurice, C.; Stubbs, R.W.; Bertozzi-Villa, A.; Morozoff, C.; Charara, R.; Allen, C.; Naghavi, M.; Murray, C.J. Trends and patterns of disparities in cancer mortality among US counties, 1980-2014. JAMA 2017, 317, 388-406. [CrossRef] [PubMed]

4. Clarke, M.F.; Dick, J.E.; Dirks, P.B.; Eaves, C.J.; Jamieson, C.H.; Jones, D.L.; Visvader, J.; Weissman, I.L.; Wahl, G.M. Cancer stem cells-perspectives on current status and future directions: AACR workshop on cancer stem cells. Cancer Res. 2006, 66, 9339-9344. [CrossRef] [PubMed]

5. Clarke, M.F.; Fuller, M. Stem cells and cancer: Two faces of eve. Cell. 2006, 124, 1111-1115. [CrossRef] [PubMed]

6. Collins, A.T.; Berry, P.A.; Hyde, C.; Stower, M.J.; Maitland, N.J. Prospective identification of tumorigenic prostate cancer stem cells. Cancer Res. 2005, 65, 10946-10951. [CrossRef] [PubMed]

7. Gu, G.; Yuan, J.; Wills, M.; Kasper, S. Prostate cancer cells with stem cell characteristics reconstitute the original human tumor in vivo. Cancer Res. 2007, 67, 4807-4815. [CrossRef] [PubMed]

8. Klarmann, G.J.; Hurt, E.M.; Mathews, L.A.; Zhang, X.; Duhagon, M.A.; Mistree, T.; Thomas, S.B.; Farrar, W.L. Invasive prostate cancer cells are tumor initiating cells that have a stem cell-like genomic signature. Clin. Exp. Metastasis 2009, 26, 433-446. [CrossRef] [PubMed]

9. Hurt, E.M.; Kawasaki, B.T.; Klarmann, G.J.; Thomas, S.B.; Farrar, W.L. CD44+ CD24(-) prostate cells are early cancer progenitor/stem cells that provide a model for patients with poor prognosis. Br. J. Cancer 2008, 98, 756-765. [CrossRef] [PubMed] 
10. Goldstein, A.S.; Lawson, D.A.; Cheng, D.; Sun, W.; Garraway, I.P.; Witte, O.N. Trop2 identifies a subpopulation of murine and human prostate basal cells with stem cell characteristics. Proc. Natl. Acad. Sci. USA 2008, 105, 20882-20887. [CrossRef] [PubMed]

11. Jiao, J.; Hindoyan, A.; Wang, S.; Tran, L.M.; Goldstein, A.S.; Lawson, D.; Chen, D.; Li, Y.; Guo, C.; Zhang, B.; et al. Identification of CD166 as a surface marker for enriching prostate stem/progenitor and cancer initiating cells. PLoS ONE 2012, 7, e42564. [CrossRef] [PubMed]

12. Collins, A.T.; Maitland, N.J. Prostate cancer stem cells. Eur. J. Cancer 2006, 42, 1213-1218. [CrossRef] [PubMed]

13. Richardson, G.D.; Robson, C.N.; Lang, S.H.; Neal, D.E.; Maitland, N.J.; Collins, A.T. CD133, a novel marker for human prostatic epithelial stem cells. J. Cell. Sci. 2004, 117, 3539-3545. [CrossRef] [PubMed]

14. Patrawala, L.; Calhoun, T.; Schneider-Broussard, R.; Li, H.; Bhatia, B.; Tang, S.; Reilly, J.G.; Chandra, D.; Zhou, J.; Claypool, K.; et al. Highly purified CD44+ prostate cancer cells from xenograft human tumors are enriched in tumorigenic and metastatic progenitor cells. Oncogene 2006, 25, 1696-1708. [CrossRef] [PubMed]

15. Rybak, A.P.; He, L.; Kapoor, A.; Cutz, J.C.; Tang, D. Characterization of sphere-propagating cells with stem-like properties from DU145 prostate cancer cells. Biochim. Biophys. Acta 2011, 1813, 683-694. [CrossRef] [PubMed]

16. Salvatori, L.; Caporuscio, F.; Verdina, A.; Starace, G.; Crispi, S.; Nicotra, M.R.; Russo, A.; Calogero, R.A.; Morgante, E.; Natali, P.G.; et al. Cell-to-cell signaling influences the fate of prostate cancer stem cells and their potential to generate more aggressive tumors. PLoS ONE 2012, 7, e31467. [CrossRef] [PubMed]

17. van Leenders, G.J.; Sookhlall, R.; Teubel, W.J.; de Ridder, C.M.; Reneman, S.; Sacchetti, A.; Vissers, K.J.; van Weerden, W.; Jenster, G. Activation of c-MET induces a stem-like phenotype in human prostate cancer. PLoS ONE 2011, 6, e26753. [CrossRef] [PubMed]

18. Kangwan, N.; Park, J.M.; Kim, E.H.; Hahm, K.B. Chemoquiescence for ideal cancer treatment and prevention: Where are we now? J. Cancer Prev. 2014, 19, 89-96. [CrossRef] [PubMed]

19. MacFarlane, M. TRAIL-induced signalling and apoptosis. Toxicol Lett. 2003, 139, 89-97. [CrossRef]

20. Oldenhuis, C.N.; Stegehuis, J.H.; Walenkamp, A.M.; de Jong, S.; de Vries, E.G. Targeting TRAIL death receptors. Curr. Opin. Pharmacol. 2008, 8, 433-439. [CrossRef] [PubMed]

21. Lim, B.; Allen, J.E.; Prabhu, V.V.; Talekar, M.K.; Finnberg, N.K.; El-Deiry, W.S. Targeting TRAIL in the treatment of cancer: New developments. Expert Opin. Ther. Targets 2015, 19, 1171-1185. [CrossRef] [PubMed]

22. Pan, G.; Ni, J.; Wei, Y.F.; Yu, G.; Gentz, R.; Dixit, V.M. An antagonist decoy receptor and a death domain-containing receptor for TRAIL. Science 1997, 277, 815-818. [CrossRef] [PubMed]

23. Mahalingam, D.; Oldenhuis, C.N.; Szegezdi, E.; Giles, F.J.; de Vries, E.G.; de Jong, S.; Nawrocki, S.T. Targeting TRAIL towards the clinic. Curr. Drug Targets 2011, 12, 2079-2090. [CrossRef] [PubMed]

24. Signore, M.; Ricci-Vitiani, L.; De Maria, R. Targeting apoptosis pathways in cancer stem cells. Cancer Lett. 2013, 332, 374-382. [CrossRef] [PubMed]

25. Seidenfeld, J.; Samson, D.J.; Hasselblad, V.; Aronson, N.; Albertsen, P.C.; Bennett, C.L.; Wilt, T.J. Single-therapy androgen suppression in men with advanced prostate cancer: A systematic review and meta-analysis. Ann. Intern. Med. 2000, 132, 566-577. [CrossRef] [PubMed]

26. Karantanos, T.; Corn, P.G.; Thompson, T.C. Prostate cancer progression after androgen deprivation therapy: Mechanisms of castrate resistance and novel therapeutic approaches. Oncogene 2013, 32, 5501-5511. [CrossRef] [PubMed]

27. de Bono, J.S.; Logothetis, C.J.; Molina, A.; Fizazi, K.; North, S.; Chu, L.; Chi, K.N.; Jones, R.J.; Goodman, O.B.; Saad, F.; et al. Abiraterone and increased survival in metastatic prostate cancer. N. Engl. J. Med. 2011, 364, 1995-2005. [CrossRef] [PubMed]

28. Scher, H.I.; Fizazi, K.; Saad, F.; Taplin, M.E.; Sternberg, C.N.; Miller, K.; de Wit, R.; Mulders, P.; Chi, K.N.; Shore, N.D.; et al. Increased survival with enzalutamide in prostate cancer after chemotherapy. N. Engl. J. Med. 2012, 367, 1187-1197. [PubMed]

29. Schweizer, M.T.; Antonarakis, E.S. Abiraterone and other novel androgen-directed strategies for the treatment of prostate cancer: A new era of hormonal therapies is born. Ther. Adv. Urol. 2012, 4, 167-178. [CrossRef] [PubMed]

30. Ni, J.; Cozzi, P.; Hao, J.; Duan, W.; Graham, P.; Kearsley, J.; Li, Y. Cancer stem cells in prostate cancer chemoresistance. Curr. Cancer Drug Targets 2014, 14, 225-240. [CrossRef] [PubMed] 
31. Yun, E.J.; Zhou, J.; Lin, C.J.; Hernandez, E.; Fazli, L.; Gleave, M.; Hsieh, J.T. Targeting cancer stem cells in castration-resistant prostate cancer. Clin. Cancer Res. 2016, 22, 670-679. [CrossRef] [PubMed]

32. Sharifi, N.; Kawasaki, B.T.; Hurt, E.M.; Farrar, W.L. Stem cells in prostate cancer: Resolving the castrate-resistant conundrum and implications for hormonal therapy. Cancer Biol. Ther. 2006, 5, 901-906. [CrossRef] [PubMed]

33. Qin, J.; Liu, X.; Laffin, B.; Chen, X.; Choy, G.; Jeter, C.R.; Calhoun-Davis, T.; Li, H.; Palapattu, G.S.; Pang, S.; et al. The PSA(-/lo) prostate cancer cell population harbors self-renewing long-term tumor-propagating cells that resist castration. Cell Stem Cell 2012, 10, 556-569. [CrossRef] [PubMed]

34. Vander Griend, D.J.; Karthaus, W.L.; Dalrymple, S.; Meeker, A.; DeMarzo, A.M.; Isaacs, J.T. The role of CD133 in normal human prostate stem cells and malignant cancer-initiating cells. Cancer Res. 2008, 68, 9703-9711. [CrossRef] [PubMed]

35. Jiang, W.; Peng, J.; Zhang, Y.; Cho, W.C.; Jin, K. The implications of cancer stem cells for cancer therapy. Int. J. Mol. Sci. 2012, 13, 16636-16657. [CrossRef] [PubMed]

36. Taylor, R.A.; Toivanen, R.; Risbridger, G.P. Stem cells in prostate cancer: Treating the root of the problem. Endocr. Relat. Cancer 2010, 17, R273-R285. [CrossRef] [PubMed]

37. Signoretti, S.; Loda, M. Prostate stem cells: From development to cancer. Semin. Cancer Biol. 2007, 17, $219-224$. [CrossRef] [PubMed]

38. Maitland, N.J.; Bryce, S.D.; Stower, M.J.; Collins, A.T. Prostate cancer stem cells: A target for new therapies. Ernst. Schering Found. Symp. Proc. 2006, 155-179.

39. Botchkina, G.I.; Zuniga, E.S.; Rowehl, R.H.; Park, R.; Bhalla, R.; Bialkowska, A.B.; Johnson, F.; Golub, L.M.; Zhang, Y.; Ojima, I.; et al. Prostate cancer stem cell-targeted efficacy of a new-generation taxoid, SBT-1214 and novel polyenolic zinc-binding curcuminoid, CMC2.24. PLoS ONE 2013, 8, e69884. [CrossRef] [PubMed]

40. Maitland, N.J.; Collins, A.T. Prostate cancer stem cells: A new target for therapy. J. Clin. Oncol. 2008, 26, 2862-2870. [CrossRef] [PubMed]

41. $\mathrm{Xu}$, J.; Zhou, J.Y.; Wu, G.S. Tumor necrosis factor-related apoptosis-inducing ligand is required for tumor necrosis factor $\alpha$-mediated sensitization of human breast cancer cells to chemotherapy. Cancer Res. 2006, 66, 10092-10099. [CrossRef] [PubMed]

42. Xu, J.; Zhou, J.Y.; Tainsky, M.A.; Wu, G.S. Evidence that tumor necrosis factor-related apoptosis-inducing ligand induction by 5-aza-2'-deoxycytidine sensitizes human breast cancer cells to adriamycin. Cancer Res. 2007, 67, 1203-1211. [CrossRef] [PubMed]

43. Daigeler, A.; Chromik, A.M.; Geisler, A.; Bulut, D.; Hilgert, C.; Krieg, A.; Klein-Hitpass, L.; Lehnhardt, M.; Uhl, W.; Mittelkötter, U. Synergistic apoptotic effects of taurolidine and TRAIL on squamous carcinoma cells of the esophagus. Int. J. Oncol. 2008, 32, 1205-1220. [CrossRef] [PubMed]

44. Wang, S.; El-Deiry, W.S. Requirement of p53 targets in chemosensitization of colonic carcinoma to death ligand therapy. Proc. Natl. Acad. Sci. USA 2003, 100, 15095-15100. [CrossRef] [PubMed]

45. Baritaki, S.; Huerta-Yepez, S.; Sakai, T.; Spandidos, D.A.; Bonavida, B. Chemotherapeutic drugs sensitize cancer cells to TRAIL-mediated apoptosis: Up-regulation of DR5 and inhibition of yin yang 1. Mol. Cancer Ther. 2007, 6, 1387-1399. [CrossRef] [PubMed]

46. Wu, X.X.; Jin, X.H.; Zeng, Y.; El Hamed, A.M.; Kakehi, Y. Low concentrations of doxorubicin sensitizes human solid cancer cells to tumor necrosis factor-related apoptosis-inducing ligand (TRAIL)-receptor (R) 2-mediated apoptosis by inducing TRAIL-R2 expression. Cancer Sci. 2007, 98, 1969-1976. [CrossRef] [PubMed]

47. Hunter, T.B.; Manimala, N.J.; Luddy, K.A.; Catlin, T.; Antonia, S.J. Paclitaxel and TRAIL synergize to kill paclitaxel-resistant small cell lung cancer cells through a caspase-independent mechanism mediated through AIF. Anticancer Res. 2011, 31, 3193-3204. [PubMed]

48. Li, L.; Wen, X.Z.; Bu, Z.D.; Cheng, X.J.; Xing, X.F.; Wang, X.H.; Zhang, L.H.; Guo, T.; Du, H.; Hu, Y.; et al. Paclitaxel enhances tumoricidal potential of TRAIL via inhibition of MAPK in resistant gastric cancer cells. Oncol. Rep. 2016, 35, 3009-3017. [CrossRef] [PubMed]

49. Nimmanapalli, R.; Perkins, C.L.; Orlando, M.; O’Bryan, E.; Nguyen, D.; Bhalla, K.N. Pretreatment with paclitaxel enhances apo-2 ligand/tumor necrosis factor-related apoptosis-inducing ligand-induced apoptosis of prostate cancer cells by inducing death receptors 4 and 5 protein levels. Cancer Res. 2001, 61, 759-763. [PubMed]

50. Yoo, J.; Park, S.S.; Lee, Y.J. Pretreatment of docetaxel enhances TRAIL-mediated apoptosis in prostate cancer cells. J. Cell. Biochem. 2008, 104, 1636-1646. [CrossRef] [PubMed] 
51. Wei, W.; Hu, H.; Tan, H.; Chow, L.W.; Yip, A.Y.; Loo, W.T. Relationship of CD44+CD24- /low breast cancer stem cells and axillary lymph node metastasis. J. Transl. Med. 2012, 10, S6. [CrossRef] [PubMed]

52. Sheridan, C.; Kishimoto, H.; Fuchs, R.K.; Mehrotra, S.; Bhat-Nakshatri, P.; Turner, C.H.; Goulet, R.; Badve, S.; Nakshatri, H. CD44+/CD24- breast cancer cells exhibit enhanced invasive properties: An early step necessary for metastasis. Breast Cancer Res. 2006, 8, R59. [CrossRef] [PubMed]

53. Liu, T.; Xu, F.; Du, X.; Lai, D.; Zhao, Y.; Huang, Q.; Jiang, L.; Huang, W.; Cheng, W.; Liu, Z. Establishment and characterization of multi-drug resistant, prostate carcinoma-initiating stem-like cells from human prostate cancer cell lines 22RV1. Mol. Cell. Biochem. 2010, 340, 265-273. [CrossRef] [PubMed]

54. Zhang, L.; Jiao, M.; Li, L.; Wu, D.; Wu, K.; Li, X.; Zhu, G.; Dang, Q.; Wang, X.; Hsieh, J.T.; et al. Tumorspheres derived from prostate cancer cells possess chemoresistant and cancer stem cell properties. J. Cancer Res. Clin. Oncol. 2012, 138, 675-686. [CrossRef] [PubMed]

55. Iczkowski, K.A. Cell adhesion molecule CD44: Its functional roles in prostate cancer. Am. J. Transl. Res. 2010, 3, 1-7. [PubMed]

56. Sastry, K.S.; Al-Muftah, M.A.; Li, P.; Al-Kowari, M.K.; Wang, E.; Ismail Chouchane, A.; Kizhakayil, D.; Kulik, G.; Marincola, F.M.; Haoudi, A.; et al. Targeting proapoptotic protein BAD inhibits survival and self-renewal of cancer stem cells. Cell Death Differ. 2014, 21, 1936-1949. [CrossRef] [PubMed]

57. Mastelić, A.; Čikeš Čulić, V.; Režić Mužinić, N.; Vuica-Ross, M.; Barker, D.; Leung, E.Y.; Reynisson, J.; Markotić, A. Glycophenotype of breast and prostate cancer stem cells treated with thieno[2,3-b]pyridine anticancer compound. Drug Des. Devel. Ther. 2017, 11, 759-769. [CrossRef] [PubMed]

58. Deshmukh, A.; Kumar, S.; Arfuso, F.; Newsholme, P.; Dharmarajan, A. Secreted frizzled-related protein 4 (sFRP4) chemo-sensitizes cancer stem cells derived from human breast, prostate, and ovary tumor cell lines. Sci. Rep. 2017, 7, 2256. [CrossRef] [PubMed]

59. Wang, P.; Henning, S.M.; Heber, D.; Vadgama, J.V. Sensitization to docetaxel in prostate cancer cells by green tea and quercetin. J. Nutr. Biochem. 2015, 26, 408-415. [CrossRef] [PubMed]

60. Berndtsson, M.; Konishi, Y.; Bonni, A.; Hägg, M.; Shoshan, M.; Linder, S.; Havelka, A.M. Phosphorylation of BAD at ser-128 during mitosis and paclitaxel-induced apoptosis. FEBS Lett. 2005, 579, 3090-3094. [CrossRef] [PubMed]

61. Tseng, H.Y.; Jiang, C.C.; Croft, A.; Tay, K.H.; Thorne, R.F.; Yang, F.; Liu, H.; Hersey, P.; Zhang, X.D. Contrasting effects of nutlin-3 on TRAIL- and docetaxel-induced apoptosis due to upregulation of TRAIL-R2 and Mcl-1 in human melanoma cells. Mol. Cancer Ther. 2010, 9, 3363-3374. [CrossRef] [PubMed] 